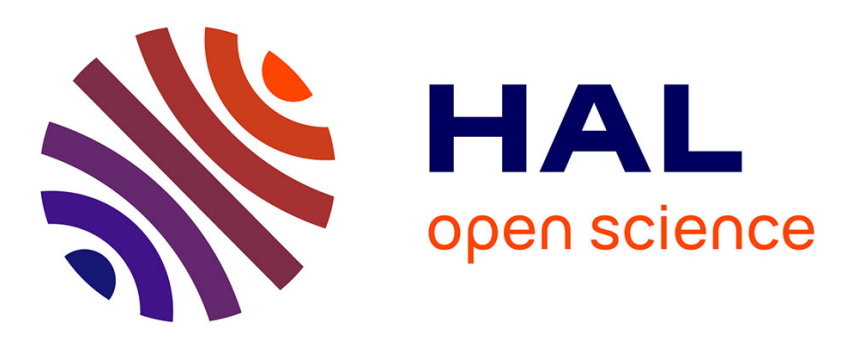

\title{
Effect of bacterial nanocellulose on the fresh and hardened states of oil well
}

\author{
Juan Cruz Barría, Analía Vazquez, Jean-Michel Pereira, Diego Manzanal
}

\section{To cite this version:}

Juan Cruz Barría, Analía Vazquez, Jean-Michel Pereira, Diego Manzanal. Effect of bacterial nanocellulose on the fresh and hardened states of oil well. Journal of Petroleum Science and Engineering, 2021, 199, pp.108259. 10.1016/j.petrol.2020.108259 . hal-03169623

\section{HAL Id: hal-03169623 \\ https: / hal-enpc.archives-ouvertes.fr/hal-03169623}

Submitted on 17 Mar 2021

HAL is a multi-disciplinary open access archive for the deposit and dissemination of scientific research documents, whether they are published or not. The documents may come from teaching and research institutions in France or abroad, or from public or private research centers.
L'archive ouverte pluridisciplinaire HAL, est destinée au dépôt et à la diffusion de documents scientifiques de niveau recherche, publiés ou non, émanant des établissements d'enseignement et de recherche français ou étrangers, des laboratoires publics ou privés. 
 cement} Effect of bacterial nanocellulose on the fresh and hardened states of oil well

3 Juan Cruz Barría ${ }^{1,3}$, Analía Vazquez², Jean-Michel Pereira ${ }^{3}$, Diego 4 Manzanal ${ }^{1,4,5}$ *

(1) Universidad Nacional de la Patagonia, Facultad de Ingeniería, Dpto. Ingeniería Civil, CONICET, RP No1 km4, Ciudad Universitaria, 9005, Comodoro Rivadavia, Argentina

(2) Universidad de Buenos Aires (UBA), Facultad de Ingeniería, LAME, Av. Las Heras 2214, 1426, Buenos Aires, Argentina, Av. Las Heras 2214, Buenos Aires, Argentina

(3) Navier, Ecole des Ponts, Univ Gustave Eiffel, CNRS, Marne-la-Vallée, France.

(4) Instituto de Tecnología y Ciencias de la Ingeniería (INTECIN), Universidad de Buenos Aires (UBA), CONICET, Facultad de Ingeniería, Av. Las Heras 2214, 1426, Buenos Aires, Argentina.

(5) ETS de Ingenieros de Caminos, Canales y Puertos, Universidad Politécnica de Madrid, c/ Prof. Aranguren 3, Ciudad Universitaria, 28040, Madrid, Spain (Current).

${ }^{*}$ corresponding author: d.manzanal@upm.es

\section{Abstract}

17 The evaluation of oil well cement additives is determined by the influence on the rheological

and mechanical properties of the slurry. The use of nanoadditives for cement, such as

bacterial nanocellulose (BNC), has been increasing in recent years due to their high tensile strength, high Young's modulus, and thermal resistance. However, the influence of BNC addition on the mechanical properties of the cement is not widely studied. The purpose of this work is to understand the effects caused by the addition of BNC in class G cement during the fresh and hardened states. Free fluid and high-pressure consistometry tests have been carried out in the fresh state. In the hardened state, dynamic thermomechanical analyses (DMA) and uniaxial compressive strength (UCS) tests have been performed. Additionally, thermogravimetric analysis (TGA) was carried out to determine the calcium hydroxide content and the hydration degree $(\mathrm{DOH})$. Results indicate that BNC modifies the slurry behavior by reducing the free fluid content and by incrementing consistency. Moreover, the calcium hydroxide content and $\mathrm{DOH}$ increase with the addition of BNC. The mechanical properties of BNC-cement samples are increased in terms of storage modulus and mechanical strength. These properties can improve the performance of cement used 32 in cementing operations. 


\section{Keywords}

34 Bacterial Nanocellulose - Cementing - Mechanical Performance - Thermal Analysis

\section{1. Introduction}

36 Oil well cementing is a complex procedure in wellbore operations. The cement must ensure

37 the oil well integrity and prevent links between formations (Al Ramadan et al., 2019; Kiran 38 et al., 2017). The slurry used differs from each particularly well condition, changing its 39 additives and quantities as needed. This cement mixture must meet a series of 40 requirements according to Standards, and it will be subjected to several stress loadings 41 throughout its life span. Different problems arise during these stages, but the low tensile 42 strength and cracks propagation of the set cement (Banthia and Nandakumar, 2003) and 43 its resistance to temperature are essential properties to be optimized, as well as.

44 Recently, there has been a growing interest in nanocellulose (Charreau et al., 2012). 45 Nanocellulose has a background in reducing micro-cracking (Hisseine et al., 2019, 2018). 46 Its addition to cement is very likely to induce an increment in tensile strength and prevent 47 the propagation of cracks caused by external loads. There are three types of nanocellulose 48 according to how is production; microfibrillated nanocellulose (MFC), nanocrystalline 49 cellulose (NCC), and bacterial nanocellulose (BNC).

50 Bacterial nanocellulose is an environmentally friendly material (Muhd Julkapli and Bagheri, 51 2017) produced by several bacteria types in different culture media. In particular, 52 Gluconacetobacter xylinus bacteria is one of the primary microbial producers of this 53 material, and its research is still ongoing (Keshk, 2014), with essential advances about 54 bacterial cultivation (Mikkelsen et al., 2009) (Vazquez et al., 2013). New studies on the 55 cost-effectiveness of culture media are making its production a significant subject of 56 interest for industrial applications (Jozala et al., 2016).

57 Recently, there has been new production of bacterial nanocellulose utilizing residues from 58 the wine industry and using steep corn liquor, which demonstrated a four-time higher yield 59 of this product in an inexpensive fermentation medium (Cerrutti et al., 2016). This increase 60 in quantity becomes significant after 21 days of incubation, and also its structure is more 
61 compact and dense because it generates a more substantial number of branches that 62 intertwine with each other (Sheykhnazari et al., 2011). These denser nanocellulose fibers 63 are obtained with nanometric widths in the ranges of 18 to $57 \mathrm{~nm}$ and micrometers in length, 64 thus obtaining a high specific surface area material.

65 Several authors have proved that nanocellulose improves the mechanical, thermal, and 66 microstructural properties of cement-based compounds (Sun et al., 2016; Vazquez et al., 67 2013, Barria et al., 2018, 2019, 2020a,b). Mainly, studies focused on the research of MFC, 68 and NCC. The improved properties were compressive strength, thermal performance, 69 degree of hydration, viscosity and water retention of cement (de Paula et al., 2014; Gómez 70 Hoyos et al., 2013; Mejdoub et al., 2017; Savastano et al., 2005).

71 However, there are few studies on the Bacterial nanocellulose (BNC) (Mohammadkazemi 72 et al., 2017, 2015, Barria et al. 2018, 2019). Recently, BNC has been used to modify 73 properties of the drilling fluids, enhanced oil recovery (EOR), and oil well cementing 74 (Ramasamy and Amanullah, 2020). BNC is estimated to have a similar effect of that MFC 75 and NCC on cement. The use of BNC in cement mortars shows an improvement in flexural 76 and compressive strength (Akhlaghi et al., 2020).

77 Therefore, the study of bacterial nanocellulose as an additive for oil well cement class $\mathrm{G}$ is 78 an exciting alternative to improve its performance in petroleum engineering applications. 79 The purpose of this work is to understand the changes due to the use of bacterial 80 nanocellulose (BNC) as an additive in class $\mathrm{G}$ oil-well cement during fresh and hardened 81 states. We examine the rheological behavior of an oil well cement slurry modified with 82 different percentages of BNC by performing free fluid and consistometry tests. The thermal 83 and mechanical behavior of cement class $\mathrm{G}$ with different BNC content is analyzed by 84 dynamic mechanical analysis (DMA) and unconfined compression strength (UCS) test. In addition, the degree of hydration $(\mathrm{DOH})$ of the cement paste with the addition of BNC performing a thermogravimetric analysis (TGA) is investigated. 


\section{Materials}

The cement used in this study was a Class G Portland Cement provided by PCR S.A. (Petroquímica Comodoro Rivadavia S.A., Argentina). It is made with clinker and calcium sulfate of high sulfate resistance grade to satisfy the chemical requirements of the American Petroleum Institute (API) Specification 10A for cement (API Specification 10A, 2019): $C_{3} S 52.8 \%, C_{3} A 1.6 \%, C_{2} S 21.1 \%$ and $C_{4} A F 15.5 \%$. The chemical composition was obtained by X-ray fluorescence (XRF) and is given in Table 1. The XRF system consists of an X-ray generator tube, collimators, crystals, and beam detectors. The excitation of the atoms from the $\mathrm{X}$-rays emits radiation that is detected by the equipment, thus quantifying the chemical composition of the cement.

Bacterial nanocellulose (BNC) is a polymer derived from cellulose obtained from the aerobic fermentation of bacteria of the genus Gluconacetobacter as the primary extracellular metabolite (Charreau et al., 2012). It was provided by a spinoff of ITPNCONICET (Nanocellu-Ar) in the form of a membrane in sealed jars (Cerrutti et al., 2016). The nanocellulose has a repetitive molecular structure composed of a linear backbone of $\beta(1-4)$-linked d-glucose units (Cerrutti et al., 2016; Vázquez and Pique, 2017). The difference between BNC and other polymers relies on the fact that it does not possess free macromolecules; it is a membrane formed by micrometric fibers of nanometric thickness. Fig. 1 shows the bacteria and the interconnected nanocellulose network. These membranes contain approximately $98 \%$ water and $2 \%$ BNC.

Deionized water and a superplasticizer were used in the mixture. The superplasticizer (SP) additive used was the ADVA 175 LN High-Performance Water-Reducing Admixture with a light-yellow liquid appearance and a density of $1.06 \mathrm{~g} / \mathrm{cm}^{3}$. It is an additive with characteristics like those of a polycarboxylate (Puertas et al., 2005). 


\section{3. Sample preparations and experimental method}

\section{$118 \quad 3.1$ Sample preparation}

119 The slurry samples were mixed according to API specifications. A high-speed mixer with 120 an API standard blade type was used (API Specification 10A, 2019). The mixing procedure 121 consisted of 15 seconds of a rotation speed of $4.000 \pm 200 \mathrm{rpm}$, and then, 35 seconds of $12212.000 \pm 500 \mathrm{rpm}$. The cement was passed through an ASTM No. 20 sieve. Each sample 123 was prepared with $792 \pm 0.5 \mathrm{~g}$ of cement and $349 \pm 0.5 \mathrm{~g}$ of distiller water at a temperature 124 of $23 \pm 1^{\circ} \mathrm{C}$

125 BNC membranes were wet-grinded to obtain the BNC additive. Then, the BNC-distilled 126 water mixture was conditioned in a $6.5 \mathrm{~L}$ Arcano ultrasonic bath with a frequency of 40.000 $127 \mathrm{~Hz}$ for 30 minutes. This procedure breaks up the nanocellulose agglomerates fibers (Fig. 128 2). The use of the ultrasound technique improves the mechanical properties of the mixture 129 by dispersing the nanocellulose and generating a more homogeneous paste (Barbash et 130 al., 2016). The BNC proportion was determined by weighing three representative samples 131 from the additive before and after placing the samples inside an oven for 24 hours. Free 132 water was evaporated, and the average quantity of BNC obtained was approximately $1330.46 \%$. Afterward, the BNC-distilled water mixture was placed in the high-speed mixer 134 according to the percentage of BNC addition. Additional distiller water with SP was added 135 to obtain a W/C ratio of 0.44 by weight.

136 The addition of BNC can improve specific properties of the cement, such as an increase in 137 the degree of hydration (Cao et al., 2015), an increase in mechanical strength (Sun et al., 138 2017), and this may reduce porosity. However, the addition also generates changes in the 139 rheological properties of the slurry (Hoyos et al., 2019). Since the previous studies 140 contemplate the changes produced by the use of different types of nanofibers, this work 141 aims to perform comprehensive research regarding the effects made only by bacterial 142 nanocellulose in the fresh and hardened states of class $\mathrm{G}$ cement. 
143 Experiments were conducted on samples with ordinary Portland cement (PC) and cement 144 modified with percentages of BNC of $0.05,0.10,0.15$, and 0.20 by weight of cement 145 (BWOC). Table 2 shows the details of each cement mixture.

$146 \quad \underline{3.2}$ Free fluid test

147 The free fluid or free water content is the volume of fluid that separates from the cement 148 slurry once the slurry remains at rest. Slurry samples of PC and modified PC with BNC 149 were performed in accordance with the API Standard 10A (API Specification 10A, 2019). 150 After the high-speed mixing (section 3.1), the slurry samples were placed in an atmospheric 151 consistometer. The atmospheric consistometer consists of a rotating cylindrical slurry 152 container equipped with a stationary pallet system. The rotational speed is $150 \pm 15 \mathrm{RPM}$. 153 The vessel was kept at a controlled temperature of $27 \pm 2{ }^{\circ} \mathrm{C}$ in an oil bath. After stirring 154 the slurry for 20 minutes \pm 30 seconds in the atmospheric consistometer, $760 \pm 5 \mathrm{~g}$ of slurry 155 were transferred directly to a $0.5 \mathrm{~L}$ Erlenmeyer flask within 1 minute of completion of mixing. 156 The flask was kept on an anti-vibration surface for 2 hours, and the excess liquid at the top 157 was removed and measured with a pipette. The percentage of free liquid was calculated 158 using the following formula:

$159 \varphi=\frac{V_{F F} \cdot \rho}{m_{s}} \cdot 100$

160 Where $\varphi$ is the volume fraction of free fluid expressed as a percentage, $V_{F F}$ is the volume 161 collected with the pipette, $m_{s}$ is the mass of the slurry in grams and $\rho$ is the density of the 162 slurry in $\mathrm{g} / \mathrm{cm}^{3}$ which is associated with the cement density.

163 The cement density was obtained following the IRAM 1624 Standard. The cement $(64 \mathrm{~g})$ 164 was placed into a Le Chatelier flask containing $0.5 \mathrm{~cm}^{3}$ of kerosene at room temperature 165 of $20 \pm 2{ }^{\circ} \mathrm{C}$ and relative humidity $50 \%$. After removing the retained air, the final reading 166 was measured after $150 \pm 30 \mathrm{~min}$. The cement density obtained was $3.18 \pm 0.01 \mathrm{~g} / \mathrm{cm}^{3}$. 167 The slurry density associated is $1.91 \mathrm{~g} / \mathrm{cm}^{3}$.

$168 \quad 3.3$ High-pressure Consistometer 
169 Cementing a wellbore requires a cement slurry capable of maintaining an adequate state 170 of pumpability under downhole conditions over a specific range of time. Thickening time 171 was determined with a high-temperature and high-pressure consistometer following the 172 API Specification 10A (API Specification 10A, 2019). The consistency of the slurry over 173 time is measured in Bearden units $\left(B_{C}\right)$.

174 The cement slurry (section 3.1) was poured into a standardized container and stirred at a 175 constant speed. A ramp of temperature and pressure over time was applied to the system 176 until Bearden unit of consistency reached $100 \mathrm{Bc}$ for a specific time. This time is known as 177 the thickening time of cement. The consistency should be less than 30Bc between 15 and 17830 minutes after the beginning of the test to ensure adequate initial consistency. In the 179 field, the time to 100 Bearden units represents the amount of time cement remains 180 pumpable under well conditions. Bearden units are dimensionless, cannot be converted to 181 any viscosity unit, and can only be determined by the high pressure and temperature 182 consistometer.

\section{$183 \quad 3.4$ Thermogravimetric analysis}

184 Cement is a porous multi-phasic material whose main components are hydrated calcium 185 silicate, calcium hydroxide, and calcium aluminate hydrate. When comparing two different 186 cement types of the same age, the calculation of the hydration degree is useful. It estimates 187 the amount of anhydrous cement that has reacted with water to form the cement hydrates. 188 The quantity of calcium hydroxide and the hydration degree can be obtained from the 189 thermogravimetric analysis.

190 The determination of non-evaporable water, calcium hydroxide $(\mathrm{CH})$, and hydration degree $191(\mathrm{DOH})$ was carried out by the technique of thermogravimetric analysis. The TGA-50 192 Shimadzu equipment consists of a precision balance, where the sample was placed inside 193 a platinum tray in a nitrogen atmosphere and a furnace that was programmed to increase 194 the temperature from 25 to $800{ }^{\circ} \mathrm{C}$ at a constant heating rate of $10{ }^{\circ} \mathrm{C} / \mathrm{min}$ with a constant 195 temperature hold at $140{ }^{\circ} \mathrm{C}$ for $15 \mathrm{~min}$. Finally, the tests ended when the temperature 196 reached $800{ }^{\circ} \mathrm{C}$ and was maintained for 1 minute. 
197 A total of five samples were crushed and analyzed in the TGA, one for each percentage of 198 nanocellulose (0\%; 0.05\%; 0.1\%; 0.15\%; 0.20\% BWOC). Each sample had an approximate 199 weight of $0.008 \mathrm{~g}$. The powdered material was dried at $110^{\circ} \mathrm{C}$ for 24 hours to remove free 200 water (Palou et al., 2014).

201 The portlandite content is obtained with the technique proposed by (Sun et al., 2016):

$202 \mathrm{CH}[\%]=\frac{74.09}{18.01} \cdot \mathrm{WL}_{\mathrm{CH}}[\%]$

203 Where $W L_{C H}$ is the percentage of weight loss during the test. The degree of hydration $204(\mathrm{DOH})$ is determined by relating chemically bound water (CBW) burned to the maximum 205 CBW burned for cement. The maximum CBW value in ordinary cement is $0.23 \mathrm{~g}$ of bound 206 water per $\mathrm{g}$ of a burned sample (Pane and Hansen, 2005). Therefore, the DOH of the samples studied can be calculated as the weight of CBW burned between 140 and $800{ }^{\circ} \mathrm{C}$ :

$208 \mathrm{DOH}[\%]=\frac{\left(\mathrm{w}_{140}-\mathrm{w}_{800}\right)}{0.23 \cdot \mathrm{w}_{800}} \cdot 100$

\section{$209 \quad 3.5$ Dynamic mechanical analysis}

210 Cement undergoes temperature variations during its life span when it is used as annular 211 protection for the wellbore. Cement is mechanically affected when a temperature gradient 212 is applied to it.

213 In order to evaluate the thermo-mechanical properties of cement, a dynamic mechanical 214 analysis (DMA) was performed. DMA measures these properties as a function of time and 215 temperature while the material is subjected to a periodic oscillatory force (García, 2012). In 216 this case, oscillatory bending stress. The storage modulus ( $\left.E^{\prime}\right)$ is the stiffness of the 217 material and represents the capacity of the material to store the applied energy. The loss 218 modulus ( $\left.E^{\prime \prime}\right)$ is the capacity of the material to dissipate the applied energy and is also 219 related to the viscous response of the material (Jawaid et al., 2015). The vector composition 220 between the storage modulus and loss modulus is the complex modulus (shear modulus) $221\left(E^{*}\right)$. The angle formed by these vectors is the mechanical damping factor of the material 222 (ठ) (Saba and Tahir, 2016). A material that can store a large amount of applied energy will 223 have a small angle $\delta$ (high elasticity). 
224 The dynamic mechanical analysis was performed with a Perkin-Elmer DMA 8000 225 instrument using the three-point bending mode. The deformation imposed on each pulse 226 was $0.001 \mathrm{~mm}$, with a pulse frequency of $1 \mathrm{~Hz}$. The test began at room temperature and 227 increased until $200^{\circ} \mathrm{C}$ with a constant rate of $2^{\circ} \mathrm{C} / \mathrm{min}$. For each pulse, the storage modulus 228 was measured. A total of 20 samples of $3 \mathrm{~mm} \times 9 \mathrm{~mm} \times 30 \mathrm{~mm}$ were tested, four for each 229 nanocellulose percentage (0\%; 0.05\%; 0.1\%;0.15\%; 0.20\% BWOC).

2303.6 Unconfined compressive strength (UCS)

231 After mixing according to Section 3.1, the slurry was poured into standard cubic molds of 5 $232 \mathrm{~cm}$ per side following the API specifications (ASTM International, 1999) for the subsequent 233 compressive strength tests. The molds were placed in the curing chamber at a temperature 234 of $20 \pm 1{ }^{\circ} \mathrm{C}$, and after 24 hours inside the molds, the specimens were removed and put 235 back inside the chamber. Once the curing time had passed, the axial compression test was 236 performed with planar metalheads at a velocity rate of $72 \pm 7 \mathrm{kN} / \mathrm{min}$ (Fig. 3).

237 The tests were performed using bacterial nanocellulose with percentages of $0.05 \%, 0.1 \%$, $2380.15 \%$, and $0.2 \%$, with adequate percentages of SP to obtain workability, and were cured 239 for 7 and 28 days in order to understand the compressive strength evolution over time. The 240 results are obtained from an average of 3 samples for each percentage of BNC used. The 241 absolute variation from the average was considered for the analysis.

242 A flow chart of the testing methodology is shown in Fig. 4.

243 Results and discussion

2444.1 Effect of BNC on cement slurries: free fluid content, consistency and thickening time 245 Cementing a wellbore requires a slurry capable of maintaining an adequate state of 246 flowability under downhole conditions over a specific range of time. Moreover, once the oil 247 well-cementing procedure is completed, the cement slurry requires to keep the cement 248 solids in suspension in the early and middle hydration periods. The effect of the BNC and 249 SP additions on the rheological behavior of cement slurry is analyzed through free fluid and 250 consistometer test. 
251 Fig. 5 shows the evolution of the free fluid content [\%] of Portland cement (PC) and PC + $2520.05 \%$ BNC slurries with the addition of SP. PC slurry shows $1.89 \%$ of free fluid content 253 measured by equation 1 . The free fluid of $\mathrm{PC}+0.10 \% \mathrm{SP}$ and $\mathrm{PC}+0.30 \% \mathrm{SP}$ slurries is 254 reduced by $5 \%$ and $36 \%$, respectively. The results show a clear trend of decreasing the 255 free fluid content of the PC slurries with the increment of SP addition. However, large 256 amounts of these additions will allow more air bubbles to enter into the cement paste, thus 257 incrementing cement porosity and decreasing long-term mechanical properties and 258 durability. The reduction in the free fluid with SP has been already studied, and the 259 stabilization in the slurry occurs because of the content of polycarboxylates which 260 chemically modifies the behavior of the cement in the fresh state (Moumin and Plank, $2612017)$

262 A similar trend is observed in PC slurries with the addition of $0.05 \%$ of BNC. The free fluid 263 is significantly reduced by the addition of the BNC for a given SP value, as is shown in Fig. 2645 . For the addition of $0.10 \% \mathrm{SP}$, the reduction of free fluid observed in $\mathrm{PC}+0.05 \% \mathrm{BNC}$ 265 slurry is $76 \%$ in comparison with the PC slurry. This gap decreases as the amount of SP 266 increases. For instance, the free fluid content of $\mathrm{PC}+0.05 \% \mathrm{BNC}$ is reduced $52 \%$ in 267 comparison with the PC slurry for the addition of $0.35 \%$ SP. Thereby, the limitations and 268 correct doses of SP are critical.

269 Results in the modified cement slurries with BNC might be explained by the water holding 270 capacity within the mixture of the BNC (Gómez Hoyos et al., 2013). Water is adhered to 271 the surface of BNC fibers and thickens the mixture (Balea et al., 2019). We can see in 272 previous studies that no water can be extracted if the quantity of nanocellulose applied is 273 excessive (Hoyos et al., 2019).

274 Results show that when using both nanocellulose and superplasticizer, the slurry stability 275 increases, which helps to prevent a fluid breakout. This effect of fluid breakout is usually 276 accompanied by longitudinal fluid channeling, which allows gas migration (Bonett and 277 Pafitis, 1996; Nelson, 1990; Salehi et al., 2016), and by reducing this effect on the modified 278 cement, an extension of its durability can be achieved. 
279 During wellbore cementing operations, if the cement slurry maintains a liquid state for a 280 short time, the constant pumping will damage the cementitious structure generated by its 281 initial setting. On the other hand, if the liquid state is maintained for a long time, it may delay 282 the commissioning of the well. With the addition of BNC to the cement slurry, an increase 283 in the yield stress is observed (Hoyos et al., 2019; Sun et al., 2016). However, there is no 284 clear understanding of the dynamic behavior of the modified slurry concerning temperature 285 286 changes. In order to observe the rheological behavior under temperature and pressure of the cement modified with BNC, consistometry tests were performed to PC and cement with the addition of $0.05 \%$ BNC. The initial consistency and the thickening time were evaluated for different percentages of SP to obtain slurry workability similar to PC. The results are shown in Table 3.

290 Three different tests are shown in Fig. 6; tests 1 (Portland cement), 5 and test 6 (Cement $291+0.05 \% \mathrm{BNC}$ ). Consistencies are shown along the $\mathrm{Y}$-axis versus time along the $\mathrm{X}$-axis. 292 Test 1 describes the normal curve for unmodified class $\mathrm{G}$ oil-well cement. In the cases of 293 BNC-modified slurries with additions of SP less than $0.3 \%$, samples quickly become very 294 viscous, reducing workability with consistency values above the tolerable value $(30 \mathrm{Bc})$. 295 This behavior is different from other polymers, where it has been found that a natural 296 cellulose polymer increases thickening time (Abbas et al., 2013). The difference with their experiment is that hydroxypropylmethylcellulose acted as a retarding agent to cement setting, allowing the slurry to remain in a liquid state. In our case, BNC acts like a water retainer, removing water used for workability and adsorbing it. This effect reduces the initial cement hydration, but at the same time, it considerably increases consistency in Bearden units, reducing thickening time. BNC has a width range between 18 to $57 \mathrm{~nm}$ and micrometers in length (Cerrutti et al., 2016), which can lead to a specific surface area variance between 150 and $250 \mathrm{~m}^{2} / \mathrm{g}$ (Li et al., 2017). Hence, the water employed in cement workability is now reduced to wet this new surface. The addition of $0.1 \%$ of BNC considerably increases the yield stress (Hoyos et al., 2019), while an increment of $0.4 \%$ leads to a cement paste that is impossible to flow. 
307 The consistency of BNC-modified slurries with additions of SP of $0.35 \%$ approximates to 308 the PC behavior. Despite this behavior being erratic through time, the final thickening time 309 is similar to the reference cement. However, BNC-modified slurries with additions of SP of $310 \quad 0.35 \%$ have an initial consistency higher than the PC slurry, due to the higher initial yield 311 stress. On the other hand, the modified samples with additions of SP of $0.4 \%$ present a 312 smaller initial consistency, and the thickening time is 25 min longer than the PC and 313 modified samples with additions of SP of $0.35 \%$. This effect is caused by the SP, which 314 makes the mixture more fluid and needs more time to thicken. Larger quantities of SP 315 reduce the probability of the hydration reaction and the precipitation of solid cement 316 particles during the first hours, allowing the sample to remain in a liquid state for longer.

\subsection{Effect of BNC on the degree of hydration}

318 TGA and DrTGA results are shown in Fig. 7 and Fig. 8, respectively. The content of each material phase was calculated by drawing three tangential lines on the TGA graph, and the 320 vertical difference of mass percentage between the intersections is considered the 321 decomposition of the material (Marsh and Day, 1988; Sun et al., 2016; Wild and Khatib, 322 1997). The continuous loss of mass on the graph is due to the dehydration of CSH and 323 other compounds that starts at $105{ }^{\circ} \mathrm{C}$ and continue until the end of the test (DeJong and 324 Ulm, 2007; Palou et al., 2014). The drop in mass between 420 and $480{ }^{\circ} \mathrm{C}$ is due to the 325 portlandite decomposition into $\mathrm{Ca}^{2+}$ ions and $2 \mathrm{HO}^{-}$from which $\mathrm{CaO}$ and $\mathrm{H}_{2} \mathrm{O} \uparrow$ are produced 326 (De Weerdt et al., 2011). We also can see a small drop between 600 and $650{ }^{\circ} \mathrm{C}$, which is 327 the decomposition of calcite. But considering that this cement was kept under alkaline 328 distilled water with negligible carbonation in the samples during 28 days (Tuutti, 1982) and 329 given the fact that the samples were dried in an oven at $110{ }^{\circ} \mathrm{C}$ during 24 hours, we can 330 assume that this calcite is, in fact, portlandite that was carbonated during drying and formed 331 into calcite due to accelerated carbonation in the oven, increasing the $\mathrm{CO}_{2}$ uptake (Liu et 332 al., 2001). The shape of the curves is similar for those samples with and without additions, 333 and they do not show new products due to BNC or SP addition (Ma et al., 2011). The curves 334 of $0.05 \%$ and $0.15 \%$ content of BNC cannot be distinguished. 
335 Portlandite content increases with the BNC content, as we can see in Table 4. The BNC 336 water retainer effect generates an additional source of water, which is enhancing the 337 generation of hydration products (Gómez Hoyos et al., 2013; Hisseine et al., 2019). On the 338 other hand, the degree of hydration $(\mathrm{DOH})$ is higher in all percentages of BNC compared 339 to PC. Similar behavior can be found in the literature (Sun et al., 2016). The DOH values 340 are underestimated because they were obtained at $800^{\circ} \mathrm{C}$ instead of $1100^{\circ} \mathrm{C}$. However, it 341 shows a trend in all the samples analysed.

342 Cement hydration and development of the microstructure over time are complex processes 343 whose study is not the objective of this work. However, an explanation of the increment in $344 \mathrm{DOH}$ and $\mathrm{CH}$ content is necessary. The surface free energy (SFE) is an indicator that can 345 characterize if a surface is more or less hydrophobic. The sum of the dispersive and polar 346 components gives the SFE. According to the literature, dispersive surface energy can 347 increase up to $138 \%$ by adding BNC to the cement sample (Mohammadkazemi et al., 348 2017). This causes more hydration reactions due to the increased amount of water on the 349 surfaces of the cement microstructure. Therefore, the increase in SFE explains the 350 increase in portlandite $(\mathrm{CH})$ and $\mathrm{DOH}$. Calorimetry tests on nanocellulose materials have 351 shown an increase in heat release (Cao et al., 2015; Lee et al., 2019), thus obtaining a 352 higher hydration degree. However, initially, it acts as a retarder for cement (Cao et al., 353 2016; Fu et al., 2017). Hisseine (Hisseine et al., 2019) suggested that the heat increment 354 during the calorimetry test is associated with the alkaline hydrolysis of cellulose, which 355 promotes cement hydration. Furthermore, cellulose filaments tend to release water during 356 hydration (Hisseine et al., 2018). In our experiments, BNC is in line with the nanocellulose 357 effects on cement mentioned in the literature, incrementing the hydration degree and 358 portlandite content.

3594.3 Effect of BNC on the mechanical performance: dynamic mechanical analysis and $360 \quad$ unconfined compressive strength 
361 The stiffness of the material is calculated from the deformation under load. The storage 362 modulus E' is a function of the elastic properties of the samples, and it is analogous to the 363 static modulus of elasticity or Young's Modulus.

364 The values obtained by the DMA results of the storage modulus are observed on a 365 logarithmic scale in Fig. 9. This modulus is reduced by increasing temperature. Samples with $0.15 \%$ and $0.20 \%$ of $\mathrm{BNC}$ maintain higher magnitudes than $\mathrm{PC}$ from $20^{\circ} \mathrm{C}$ to $200^{\circ} \mathrm{C}$, while $0.05 \%$ of BNC has lower values throughout the test. BNC can maintain properties while the temperature is rising in the medium, which is traceable to its thermal stability up to $350{ }^{\circ} \mathrm{C}$ (Hoyos et al., 2019). The reduction of the stiffness (E' values) during the first step until $110^{\circ} \mathrm{C}$ is due to dehydration of the free adsorbed water and some interlayered water 371 (Sereda et al., 1966) which speed up the start to micro-cracking of the sample (Evans and 372 Marathe, 1968).

373 In Fig. 10, we normalized the storage moduli to their initial values. The normalized storage 374 modulus is obtained by dividing the module measured at a certain temperature $\left(T_{i}\right)$ over its 375 initial value $\left(\mathrm{T}_{0}\right)$ for each tested sample. An important drop is observed between 110 and $376140{ }^{\circ} \mathrm{C}$, where cement samples lose between $80 \%$ and $50 \%$ of their storage modulus. This 377 drop can be explained due to water evaporation from the samples and to CSH dehydration, 378 starting at approximately $110^{\circ} \mathrm{C}$ (Foray-thevenin et al., 2006). The dehydration begins to 379 degrade the properties of the cementitious matrix because the water acts as a stabilizer of 380 the $\mathrm{CSH}$ structure. Here, cement with $0.15 \%$ of BNC has a better performance than PC 381 and cement modified with $0.05 \%$ or $0.20 \%$ of BNC. These samples are the most stable 382 mixtures, due to that quantity is better distributed in the sample. BNC acts like water 383 molecules and pulls apart the $\mathrm{CSH}$ interlayer. For the other samples, a more rapid collapse 384 of the $\mathrm{CSH}$ structure with dehydration occurs. More sliding sites, increment in the internal 385 friction, and a faster reduction of the elasticity consequently decreases quicker the value 386 of E with temperature (Alizadeh et al., 2011). At $130^{\circ} \mathrm{C}, \mathrm{PC}$ shows a lost $70 \%$ of its modulus, 387 while samples with $0.15 \%$ of BNC only lost $30 \%$. 
388 On the other hand, the storage modulus of the $0.05 \%$ BNC sample is smaller than the PC 389 samples for most of the test, except between 130 and $160{ }^{\circ} \mathrm{C}$. However, the normalized 390 module graph shows better behavior after $120^{\circ} \mathrm{C}$. This means that this small addition of 391 BNC changes the thermal properties but does not change the bending strength.

392 In Fig. 11, temperature provokes a significant impact on the PC sample, inducing higher $393 \tan \delta$, which represents the material resistance to be deformed by temperature. This effect 394 starts to be detected at $150{ }^{\circ} \mathrm{C}$ and until $200{ }^{\circ} \mathrm{C}$. On the other hand, cement with a higher 395 percentage of BNC $(0.15 \%$ and $0.20 \%)$ has not been affected as the previous one. It has 396 maintained a lower loss modulus factor ( $85 \%$ less than PC at $\left.200{ }^{\circ} \mathrm{C}\right)$, except for the 397 percentage of $0.05 \%$, where the reduction is $50 \%$. Considering the analysis of 398 nanostructure performed by Alizadeh et al. (Alizadeh et al., 2011), the behavior of $\tan \delta$ of $399 \mathrm{PC}$ and $0.05 \%$ of $\mathrm{BNC}$ is different from 0.15 and $0.20 \% \mathrm{BNC}$. This can be related to the 400 different microstructure generated due to the formation of aggregates of BNC in the mixture 401 with PC. Alizadeh et al. related the higher tan $\delta$ value to higher $\mathrm{E}$, and sliding frictional 402 effects that occur when water is evaporated from adsorbed water because water restrains 403 the $\mathrm{CSH}$ sheets. The decrease of tan $\delta$ or damping effect is the consequence of higher 404 rigidity of the nanostructure. This is the result of a higher bridging of the CSH sheets due 405 to the increases in the number of strong bonds between SI and O or Si-O_Ca. These bonds 406 are due to the dehydration of water interlayer of $\mathrm{CSH}$, which is higher for a higher content 407 of BNC.

408 As seen before on the microstructure of cement, PC has the lowest hydration degree of the 409 samples. The lower quantities and shorter length chains of $\mathrm{CH}$ are making this cement 410 more susceptible to creep (Pourbeik et al., 2013), while samples with higher hydration 411 degrees are withstanding the oscillatory loading. On the other hand, cement samples under 412 bending mode are very dependent on the material tensile strength. Fatigue crack 413 propagation depends on the applied stress, the initial crack size, and the material 414 toughness to fracture. As the applied stresses are the same (bending load and temperature 415 rate changes), the samples reinforced with BNC induce two types of changes. The first 
416 change occurs on the pre-testing cracking size (tensile strength improvement) and the 417 second one on the fracture toughness (hydration improvement). These changes explain 418 the behavior of the samples at $200^{\circ} \mathrm{C}$, where all modified samples with BNC have shown 419 higher storage modulus than PC, except with $0.05 \%$.

420 Previous studies have worked with other polymers and also found that fibers add more 421 flexural strength in cement (Jamshidi and Karimi, 2009; Parveen et al., 2017). Our results 422 show this trend on flexural strength, and now it shows improvement under thermal stresses.

423 Samples of 0.15 and $0.20 \%$ BNC increase the properties at room temperature and up to $424200^{\circ} \mathrm{C}$

425 The tensile strength of cement samples is around $10 \%$ of the unconfined compressive 426 strength for Portland cement. The addition of BNC increases the tensile stress reinforcing 427 the samples and increasing compressive strength (Parveen et al., 2017).

428 The compressive strength of BNC-cement mixtures was determined for samples cured in 429 a water bath at $20^{\circ} \mathrm{C}$ during 7 and 28 days.

430 Fig. 12 shows the normalized compressive strength of cement as a function of BNC 431 percentages cured for 7 and 28 days. The strength values $(\Delta)$ are normalized to the 432 strength value obtained after 7 days of curing in PC cement $\left(\Delta_{0}\right)$. The error bars show the 433 absolute variation obtained in the tests. The unconfined compressive strength of $\mathrm{PC}$, and 434 the mixtures $\mathrm{PC}+0.05 \%, 0.10 \%, 0.15 \%$ and $0.20 \% \mathrm{BNC}$ for different curing times is 435 presented in Fig. 13. The errors in the PC and $0.05 \%$ samples are very small in Fig 12, so 436 their error bar is not visible in the graph. To plot Figure 13, only the average values of the 437 results were used.

438 The results show an enhancement in strength for cement samples with the addition of BNC. 439 However, $\mathrm{PC}+0.15 \% \mathrm{BNC}$ and $\mathrm{PC}+0.20 \% \mathrm{BNC}$ samples at 7 days shown a decrease in 440 the strength influenced by the segregation in the mixture due to the SP (Xiaofeng et al., 441 1990). It is known that other types of nanocellulose increases compressive strength as well 442 (Hisseine et al., 2019; Lee et al., 2019; Mejdoub et al., 2017). The increase in tensile stress 443 (Cao et al., 2015), compressive strength, and hydration degree support the use of BNC as 
444 a long-term reinforcement. The hydrophilic characteristic of BNC to avoid faster water loss 445 during cement hydration is preventing the propagation of thermally induced cracking (Balea 446 et al., 2019). By decreasing these cracks, the probability of failure through them for the 447 same stress is decreased (Banthia and Nandakumar, 2003; Lee et al., 2019), allowing the 448 bulk sample to withstand more loading.

449 The strength tends to increase with the percentage of nanocellulose. A small increment in 450 BNC $(0.05 \%)$ produces an important increment in compressive strength, both at 7 days 451 and at 28 days. The addition of $0.05 \%$ BNC increases by $18 \%$ and $20 \%$ the strength in 452 comparison with cement sample (PC) cured at 7 days and 28 days, respectively. Other 453 authors also obtained a significant rise in strength for small percentages of nanocellulose 454 addition (Hisseine et al., 2019; Sun et al., 2016). The results are encouraging the use of 455 BNC in future admixtures due to its low amount of incorporation and low change in the 456 viscosity.

\section{5. Conclusions}

458 An experimental study regarding the effects produced by the addition of bacterial 459 nanocellulose (BNC) between $0.05 \%$ to $0.20 \%$ BWOC to cement was carried out. Free 460 fluid tests, high-pressure consistometry tests, thermogravimetric analysis, 461 thermomechanical analysis, and uniaxial compressive strength tests were performed.

462 Results indicate that the addition of BNC between $0.05 \%$ to $0.20 \%$ BWOC produces an 463 important decrease in the amount of free fluid.

464 The addition of BNC reduces the thickening time of cement slurry, and a dispersive agent 465 is needed to maintain the fluidity of the mixture. Nevertheless, more significant amounts of 466 dispersant increase the thickening time for the same amount of nanocellulose.

467 The thermogravimetric analysis shows an increment in hydration products and hydration 468 degree as the percentage of bacterial nanocellulose increases due to its hydrophilic 469 properties. 
470 The dynamic mechanical analysis shows an improvement in the thermoelastic behavior of 471 cement pastes by using large percentages of BNC, mainly by its thermal stability and its 472 tensile reinforcement.

473 The use of BNC in cement has shown an increment in strength development at 7 and 28 474 days. All the mixtures using bacterial nanocellulose have increased the compressive 475 strength development over time.

476 In summary, the $0.05 \%$ additions BWOC of bacterial nanocellulose have shown good 477 performance for tests with fresh and hardened cement samples. In fresh cement samples, 478 the workability is achieved with small amounts of superplasticizer, and the free fluid is 479 suitable to be used in the consistometer. The mechanical properties obtained during 480 thermo-mechanical tests (DMA) are similar to ordinary cement, but a significant increment 481 in compressive strength is observed. The results are beneficial up to $0.20 \%$ BWOC of BNC 482 used, although a more considerable amount of superplasticizer is needed to maintain the 483 fresh samples' fluidity.

484 The addition of bacterial nanocellulose between $0.05 \%$ to $0.20 \%$ BWOC improves the 485 mechanical properties of the cement due to its tensile strength and crack inhibition. Another 486 reason for this might be the increase in hydration degree, which generates more $\mathrm{CSH}$ and $487 \mathrm{CH}$ that increase its strength. The water retention of BNC increases its initial consistency. 488 However, it produces a considerable decrease in its free fluid content, which enhances its 489 hydration. Further analysis of microstructure is underway to characterize the modified 490 cement.

491 Bacterial nanocellulose proves to be an inexpensive, renewable, and high-strength material 492 that can be used as an additive to oil well cement. These characteristics can benefit the 493 cement used during well-cementing operations. Due to its low free fluid content, the 494 probability of fluid migration in the well may be reduced. The increase in thermal and 495 mechanical strength can improve the performance of the cement sheath surrounding the 496 casing, having a better behavior when supporting the stresses generated by temperature 497 gradients or induced seismic activity during water or $\mathrm{CO}_{2}$ injection scenarios. 


\section{Acknowledgment}

500 The first author gratefully acknowledges the fellowship granted by CONICET (National 501 Scientific and Technical Research Council - Argentina). The authors also acknowledged 502 the financials support of "Universidad Nacional de la Patagonia San Juan Bosco" (Project 503 UNPSJB PI1614 - 80020190200006IP, Resol R/9N²07-2020 CRD1365 FI004/17) and 504 the Agency of Scientific and Technological Promotion (Agencia Nacional de Promoción 505 Científica y Tecnológica) from Ministry of Science and Technology of Argentine Republic. 506 (Projects PICT 2016-4543). The authors express their gratitude to Petroquímica Comodoro 507 Rivadavia S.A. and its technical staff for helping with the performed tests.

\section{Abbreviations}

509 API: $\quad$ American Petroleum Institute

510 BNC: Bacterial nanocellulose

511 BWOC: By weight of cement

$512 \quad C_{3}$ S: $\quad$ Alite

$513 C_{3} A: \quad$ Calcium aluminate

$514 \quad C_{2} S$ : Belite

$515 \quad C_{4} A F: \quad$ Calcium alumino-ferrite

$516 \mathrm{CH}: \quad$ Calcium hydroxide

517 CSH: $\quad$ Calcium silicate hydrate

518 CBW: Chemical bound water

519 DMA: Dynamic mechanical analysis

520 DOH: Degree of hidration

521 DrTGA: Derivative hermogravimetric analysis

522 EOR: Enhanced oil recovery

523 MFC: $\quad$ Microfibrillated nanocellulose

524 NCC: Nanocrystalline cellulose

525 PC: Portland Cement

526 SP: Superplasticizer

527 TGA: Thermogravimetric analysis

528 UCS: Uniaxial compressive strength

529 W/C: Water to cement ratio

$530 \quad X R F: \quad X$-ray fluorescence 


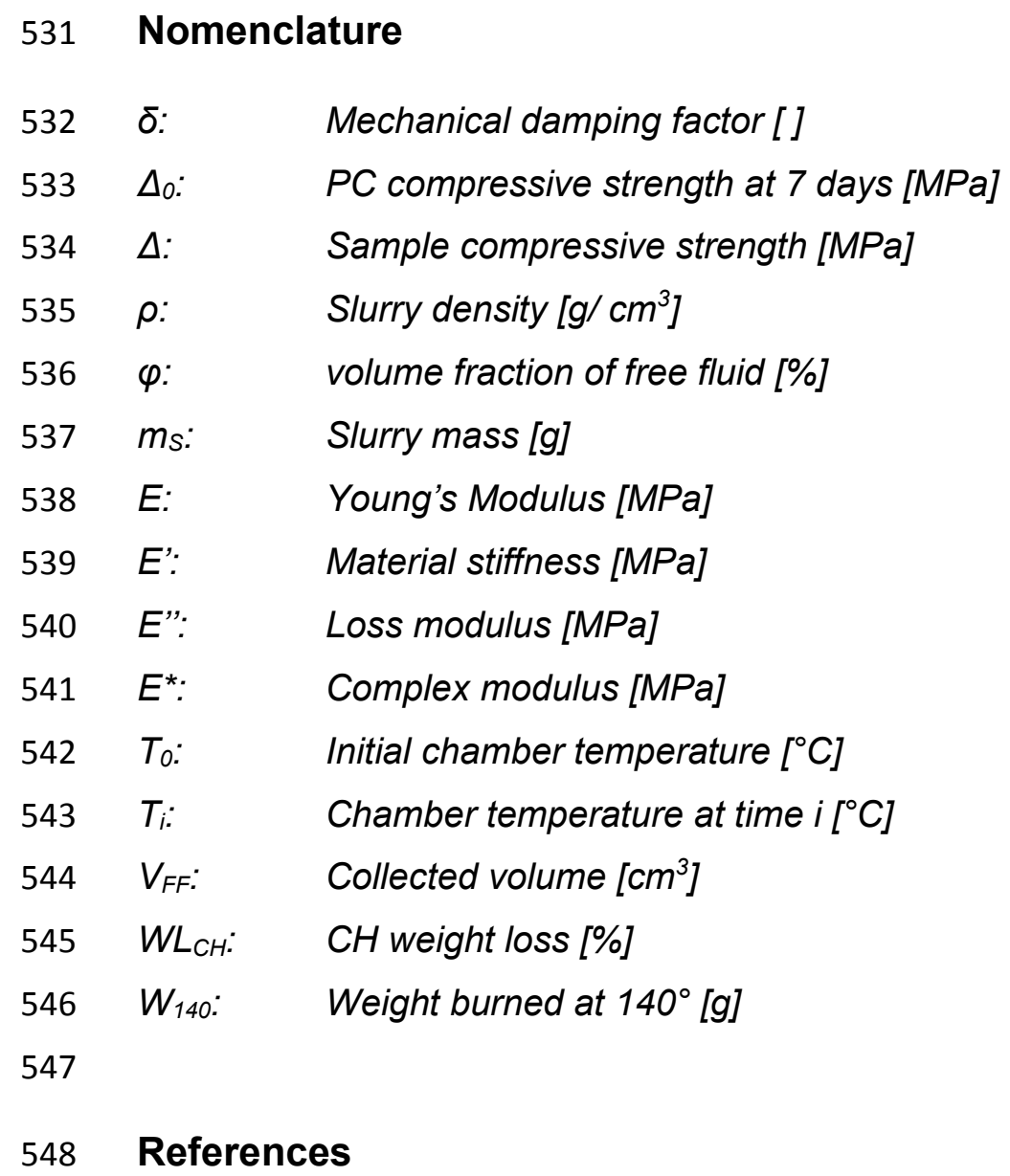

561 API Specification 10A, 2019. Specification for Cements and Materials for Well Cementing, 
Twenty-Fif. ed, American Petroleum Institute. Northwest Washington, DC.

ASTM International, 1999. ASTM C109: Standard Test Method for Compressive Strength of Hydraulic Cement Mortars. Am. Soc. Test. Mater. 04, 1-6. https://doi.org/10.1520/C0109

Balea, A., Fuente, E., Blanco, A., Negro, C., 2019. Nanocelluloses: Natural-based materials for fiber- reinforced cement composites. A critical review. Polymers (Basel). 11. https://doi.org/10.3390/polym11030518

Banthia, N., Nandakumar, N., 2003. Crack growth resistance of hybrid fiber reinforced cement composites. Cem. Concr. Compos. 25, 3-9. https://doi.org/10.1016/S09589465(01)00043-9

Barbash, V.A., Yaschenko, O. V., Alushkin, S. V., Kondratyuk, A.S., Posudievsky, O.Y., Koshechko, V.G., 2016. The Effect of Mechanochemical Treatment of the Cellulose on Characteristics of Nanocellulose Films. Nanoscale Res. Lett. 11, 16-23. https://doi.org/10.1186/s11671-016-1632-1

Barria, J.C., Martin, C., Pique, T., Pereira, J.M., Manzanal, D., 2018. Analysis of modified cement paste in the context of $\mathrm{CO} 2$ geological storage. International Symposium of Energy Geotechnics. Lugar: Laussane, Pages 402-409. Publisher: Springer, Cham. Online ISBN 978-3-319-99670-7. https://doi.org/10.1007/978-3-319-99670-7.

Barria, J.C., Manzanal, Pereira, J.M., 2019. CO2 geological storage: Performance of Cement-Rock interface. XVI Pan-American Conference on Soil Mechanics and Geotechnical Engineering 17-20 November 2019. Cancun, México. DOI: 10.3233/STAL190359

Barria, J.C., Manzanal, Pereira, J.M., Ghabezloo, S., 2020a. CO2 Geological storage: Microstructure and mechanical behaviour of cement modified with biopolymers after carbonation. E3S Web Conf. Vol. 205, 2020. 2nd International Conference on Energy Geotechnics (ICEGT 2020), section: CO2 Sequestration and Deep Geothermal Energy 18 November 2020: DOI: 10.1051/e3sconf/202020502007 Barria, J.C., Pereira, J.M., Manzanal, D., 2020b. Cement with bacterial nanocellulose 
cured at high temperature: mechanical performance in the context of $\mathrm{CO} 2$ geological storage. Geomechanics for Energy and the Environment. Under review.

Bonett, A., Pafitis, D., 1996. Getting to the root of gas migration. Oilf. Rev. 8, 36-49.

Cao, Y., Tian, N., Bahr, D., Zavattieri, P.D., Youngblood, J., Moon, R.J., Weiss, J., 2016. The influence of cellulose nanocrystals on the microstructure of cement paste. Cem. Concr. Compos. 74, 164-173. https://doi.org/10.1016/j.cemconcomp.2016.09.008

Cao, Y., Zavaterri, P., Youngblood, J., Moon, R., Weiss, J., 2015. The influence of cellulose nanocrystal additions on the performance of cement paste. Cem. Concr. Compos. 56, 73-83. https://doi.org/10.1016/j.cemconcomp.2014.11.008

Cerrutti, P., Roldán, P., García, R.M., Galvagno, M.A., Vázquez, A., Foresti, M.L., 2016. Production of bacterial nanocellulose from wine industry residues: Importance of fermentation time on pellicle characteristics. J. Appl. Polym. Sci. 133. https://doi.org/10.1002/app.43109

Charreau, H., L. Foresti, M., Vazquez, A., 2012. Nanocellulose Patents Trends: A Comprehensive Review on Patents on Cellulose Nanocrystals, Microfibrillated and Bacterial Cellulose. Recent Pat. Nanotechnol. 7, 56-80.

https://doi.org/10.2174/18722105130106

de Paula, J.N., Calixto, J.M., Ladeira, L.O., Ludvig, P., Souza, T.C.C., Rocha, J.M., de Melo, A.A.V., 2014. Mechanical and rheological behavior of oil-well cement slurries produced with clinker containing carbon nanotubes. J. Pet. Sci. Eng. 122, 274-279. https://doi.org/10.1016/j.petrol.2014.07.020

De Weerdt, K., Haha, M. Ben, Le Saout, G., Kjellsen, K.O., Justnes, H., Lothenbach, B., 2011. Hydration mechanisms of ternary Portland cements containing limestone powder and fly ash. Cem. Concr. Res. 41, 279-291. https://doi.org/10.1016/j.cemconres.2010.11.014

DeJong, M.J., Ulm, F.J., 2007. The nanogranular behavior of C-S-H at elevated temperatures (up to $700^{\circ} \mathrm{C}$ ). Cem. Concr. Res. 37, 1-12. https://doi.org/10.1016/j.cemconres.2006.09.006 
618 Evans, R.H., Marathe, M.S., 1968. Microcracking and stress-strain curves for concrete in tension. Matériaux Constr. 1, 61-64. https://doi.org/10.1007/BF02479001

Foray-thevenin, G., Vigier, G., Vassoille, R., Orange, G., 2006. Characterization of cement paste by dynamic mechanical Part I : operative conditions $56,129-137$. https://doi.org/10.1016/j.matchar.2005.10.007

Fu, T., Montes, F., Suraneni, P., Youngblood, J., Weiss, J., 2017. The influence of cellulose nanocrystals on the hydration and flexural strength of Portland cement pastes. Polymers (Basel). 9. https://doi.org/10.3390/polym9090424

García, C., 2012. Caracterización térmica y mecánica de polibutilentereftalato (PBT). Univ. politécnica Cart. Universidad Politécnica de Cartagena.

Gómez Hoyos, C., Cristia, E., Vázquez, A., 2013. Effect of cellulose microcrystalline particles on properties of cement based composites. Mater. Des. 51, 810-818. https://doi.org/10.1016/j.matdes.2013.04.060

Hisseine, O.A., Omran, A.F., Tagnit-Hamou, A., 2018. Influence of cellulose filaments on cement paste and concrete. J. Mater. Civ. Eng. 30, 1-14. https://doi.org/10.1061/(ASCE)MT.1943-5533.0002287

Hisseine, O.A., Wilson, W., Sorelli, L., Tolnai, B., Tagnit-Hamou, A., 2019. Nanocellulose for improved concrete performance: A macro-to-micro investigation for disclosing the effects of cellulose filaments on strength of cement systems. Constr. Build. Mater. 206, 84-96. https://doi.org/10.1016/j.conbuildmat.2019.02.042

Hoyos, C.G., Zuluaga, R., Gañán, P., Pique, T.M., Vazquez, A., 2019. Cellulose nanofibrils extracted from fique fibers as bio-based cement additive. J. Clean. Prod. 235, 1540-1548. https://doi.org/10.1016/j.jclepro.2019.06.292

Jamshidi, M., Karimi, M., 2009. Characterization of Polymeric Fibers as Reinforcements of Cement-Based Composites. J. Appl. Polym. Sci. 115, 2779-2785. https://doi.org/10.1002/app

Jawaid, M., Khalil, H.P.S.A., Hassan, A., Dungani, R., Hadiyane, A., 2015. Composites : Part B Effect of jute fibre loading on tensile and dynamic mechanical properties of oil 
palm epoxy composites. Compos. Part B 45, 619-624.

https://doi.org/10.1016/j.compositesb.2012.04.068

Jozala, A.F., Lencastre-novaes, L.C. De, Lopes, A.M., Santos-ebinuma, V.D.C., Mazzola, P.G., Pessoa-jr, A., 2016. Bacterial nanocellulose production and application : a 10year overview. Appl. Microbiol. Biotechnol. 100, 2063-2072. https://doi.org/10.1007/s00253-015-7243-4

Keshk, S.M.A.S., 2014. Bacterial Cellulose Production and its Industrial Applications. J. Bioprocess. Biotech. 4. https://doi.org/10.4172/2155-9821.1000150

Kiran, R., Teodoriu, C., Dadmohammadi, Y., Nygaard, R., Wood, D., Mokhtari, M., Salehi, S., 2017. Identification and evaluation of well integrity and causes of failure of well integrity barriers (A review). J. Nat. Gas Sci. Eng. 45, 511-526. https://doi.org/10.1016/j.jngse.2017.05.009

Klemm, D., Schumann, D., Kramer, F., Heßler, N., Hornung, M., Marsch, S., Gesichtschirurgie, K.-, Chirurgie, P., Jena, F., Allee, E., V, P.J., 2006. Nanocelluloses as Innovative Polymers in Research and Application. Adv. Polym. Sci. 49-96. https://doi.org/10.1007/12_097

Lee, H.J., Kim, S.K., Lee, H.S., Kim, W., 2019. A Study on the Drying Shrinkage and Mechanical Properties of Fiber Reinforced Cement Composites Using Cellulose Nanocrystals. Int. J. Concr. Struct. Mater. 13. https://doi.org/10.1186/s40069-019$0351-2$

Li, Z., Ahadi, K., Jiang, K., Ahvazi, B., Li, P., Anyia, A.O., Cadien, K., Thundat, T., 2017. Freestanding hierarchical porous carbon film derived from hybrid nanocellulose for high-power supercapacitors. Nano Res. 10, 1847-1860.

https://doi.org/10.1007/s12274-017-1573-8

Liu, L., Ha, J., Hashida, T., Teramura, S., 2001. Development of a CO2solidification method for recycling autoclaved lightweight concrete waste. J. Mater. Sci. Lett. 20, 1791-1794. https://doi.org/10.1023/A:1012591318077

Ma, B., Ou, Z., Jian, S., Xu, R., 2011. Influence of cellulose ethers on hydration products 
of portland cement. J. Wuhan Univ. Technol. Mater. Sci. Ed. 26, 588-593. https://doi.org/10.1007/s11595-011-0273-6

Marsh, B.K., Day, R.L., 1988. Pozzolanic and cementitious reaction of fly ash in blended. Cem. Concr. Res. 18, 301-310. https://doi.org/https://doi.org/10.1016/00088846(88)90014-2

Mejdoub, R., Hammi, H., Suñol, J.J., Khitouni, M., Boufi, S., 2017. Nanofibrillated cellulose as nanoreinforcement in Portland cement: Thermal, mechanical and microstructural properties. J. Compos. Mater. 51, 2491-2503. https://doi.org/10.1177/0021998316672090

Mikkelsen, D., Flanagan, B.M., Dykes, G.A., Gidley, M.J., 2009. Influence of different carbon sources on bacterial cellulose production by Gluconacetobacter xylinus strain ATCC 53524. J. Appl. Microbiol. 107, 576-583. https://doi.org/10.1111/j.13652672.2009.04226.x

Mohammadkazemi, F., Aguiar, R., Cordeiro, N., 2017. Improvement of bagasse fibercement composites by addition of bacterial nanocellulose: an inverse gas chromatography study. Cellulose 24, 1803-1814. https://doi.org/10.1007/s10570017-1210-4

Mohammadkazemi, F., Doosthoseini, K., Ganjian, E., Azin, M., 2015. Manufacturing of bacterial nano-cellulose reinforced fiber-cement composites. Constr. Build. Mater. 101, 958-964. https://doi.org/10.1016/j.conbuildmat.2015.10.093

Moumin, M., Plank, J., 2017. Effectiveness of Polycarboxylate Dispersants in Enhancing the Fluid Loss Performance of Cellulose Ethers. SPE Int. Conf. Oilf. Chem. https://doi.org/10.2118/184542-ms

Muhd Julkapli, N., Bagheri, S., 2017. Nanocellulose as a green and sustainable emerging material in energy applications: a review. Polym. Adv. Technol. 28, 1583-1594. https://doi.org/10.1002/pat.4074

Nelson, E.B., 1990. Well Cementing. Elsevier.

Palou, M.T., Šoukal, F., Boháč, M., Šiler, P., Ifka, T., Živica, V., 2014. Performance of G- 
Oil Well cement exposed to elevated hydrothermal curing conditions. J. Therm. Anal. Calorim. 118, 865-874. https://doi.org/10.1007/s10973-014-3917-x

Pane, I., Hansen, W., 2005. Investigation of blended cement hydration by isothermal calorimetry and thermal analysis. Cem. Concr. Res. 35, 1155-1164. https://doi.org/10.1016/j.cemconres.2004.10.027

Parveen, S., Rana, S., Fangueiro, R., Conceiç, M., 2017. A novel approach of developing micro crystalline cellulose reinforced cementitious composites with enhanced microstructure and mechanical performance. Cem. Concr. Compos. 78. https://doi.org/10.1016/j.cemconcomp.2017.01.004

Pourbeik, P., Alizadeh, R., Beaudoin, J.J., Nguyen, D.T., Raki, L., 2013. Microindentation creep of 45 year old hydrated Portland cement paste. Adv. Cem. Res. 25, 301-306. https://doi.org/10.1680/adcr.12.00058

Puertas, F., Santos, H., Palacios, M., Mart nez-Ram rez, S., 2005. Polycarboxylate superplasticiser admixtures: effect on hydration, microstructure and rheological behaviour in cement pastes. Adv. Cem. Res. 17, 77-89. https://doi.org/10.1680/adcr.17.2.77.65044

Ramasamy, J., Amanullah, M., 2020. Nanocellulose for oil and gas field drilling and cementing applications. J. Pet. Sci. Eng. 184. https://doi.org/10.1016/j.petrol.2019.106292

Saba, N., Tahir, P.M., 2016. A Review on Dynamic mechanical analysis of natural fibre reinforced polymer composites. Constr. Build. Mater. 106, 149-159. https://doi.org/10.1016/j.conbuildmat.2015.12.075

Salehi, S., Khattak, M., Ali, N., Rizvi, H., 2016. Laboratory Investigation of High Performance Geopolymer Based Slurries AADE-16-FTCE-88. Am. Assoc. Drill. Eng.

Savastano, H., Warden, P.G., Coutts, R.S.P., 2005. Microstructure and mechanical properties of waste fibre-cement composites, in: Cement and Concrete Composites. pp. 583-592. https://doi.org/10.1016/j.cemconcomp.2004.09.009 
mechanical properties of hydrated Portland cement pastes and compacts. Highw. Res. Board ... 58-73.

Sheykhnazari, S., Tabarsa, T., Ashori, A., Shakeri, A., Golalipour, M., 2011. Bacterial synthesized cellulose nanofibers; Effects of growth times and culture mediums on the structural characteristics. Carbohydr. Polym. 86, 1187-1191. https://doi.org/10.1016/j.carbpol.2011.06.011

Sun, X., Wu, Q., Lee, S., Qing, Y., Wu, Y., 2016. Cellulose Nanofibers as a Modifier for Rheology, Curing and Mechanical Performance of Oil Well Cement. Sci. Rep. 6, 19. https://doi.org/10.1038/srep31654

Sun, X., Wu, Q., Zhang, J., Qing, Y., Wu, Y., Lee, S., 2017. Rheology, curing temperature and mechanical performance of oil well cement: Combined effect of cellulose nanofibers and graphene nano-platelets. Mater. Des. 114, 92-101. https://doi.org/10.1016/j.matdes.2016.10.050

Tuutti, K., 1982. Corrosion of Steel in Concrete. Swedish Cem. Concr. Res. Inst. 469. https://doi.org/10.1002/9780470872864.ch49

Vazquez, A., Foresti, M.L., Cerrutti, P., Galvagno, M., 2013. Bacterial Cellulose from Simple and Low Cost Production Media by Gluconacetobacter xylinus. J. Polym. Environ. 21, 545-554. https://doi.org/10.1007/s10924-012-0541-3

Vázquez, A., Pique, T.M., 2017. Biobased Additives in Oilwell Cement, in: Industrial Applications of Renewable Biomass Products. Past, Present and Future. pp. 179198. https://doi.org/10.1007/978-3-319-61288-1

Wild, S., Khatib, J.M., 1997. Portlandite consumption in metakaolin cemen pastes and mortars. Cem. Concr. Res. 27, 137-146. https://doi.org/https://doi.org/10.1016/S0008-8846(96)00187-1

Xiaofeng, C., Shanglong, G., Darwin, D., McCabe, S.L., 1990. Role of silica fume in compressive strength of cement paste, mortar, and concrete. ACI Mater. J. 89, 375387. https://doi.org/10.14359/2570

\section{Table captions}


758 Table 1. Cement chemical composition.

(1)

760 Table 3. Consistometry test.

761 Table 4. $\mathrm{CH}$ content and $\mathrm{DOH}(\%)$ of the samples.

762 Table 5. BNC and SP percentages in cement samples.

\section{Figure captions}

764 Figure 1. Bacteria and bacterial nanocellulose (Courtesy of Cerruti et al. 2016)

765 Figure 2. Ultrasonic bath for homogenization of BNC - distilled water mixture.

766 Figure 3. Compressive strength test equipment.

767 Figure 4. Testing methodology.

768 Figure 5. Free fluid content for different percentages of superplasticizer for Portland 769 Cement $(\mathrm{PC})$ and $\mathrm{PC}+0.05 \% \mathrm{BNC}$.

770 Figure 6. Consistometry test for Portland Cement (PC), PC $+0.05 \%$ of BNC $+0.35 \%$ SP 771 and $\mathrm{PC}+0.05 \% \mathrm{BNC}+0.40 \% \mathrm{SP}$.

772 Figure 7. (a) Example of mass loss calculation for $\mathrm{CH}$ in the TGA test (b)TGA results for 773 Portland Cement (PC) and PC modified with BNC at $0.05 \%, 0.10 \%, 0.15 \%$ and $0.20 \%$ 774 BWOC.

Figure 8. DrTGA results for Portland Cement (PC) and PC modified with BNC at $0.05 \%$, 778 Figure 9. DMA results of Portland Cement (PC) and PC modified with BNC at $0.05 \%$, $7790.10 \%, 0.15 \%$ and $0.20 \%$ BWOC samples cured for 28 days.

780 Figure 10. Normalized storage modulus of Portland Cement (PC) and PC modified with 781 BNC at $0.05 \%, 0.10 \%, 0.15 \%$ and $0.20 \%$ BWOC samples cured for 28 days.

782 Figure 11 DMA results in term of tan d of Portland Cement (PC) and PC modified with BNC 783 at $0.05 \%, 0.10 \%, 0.15 \%$ and $0.20 \%$ BWOC samples cured for 28 days. 
784 Figure 12. Normalized compressive strength of Portland Cement (PC) and PC modified 785 with BNC at $0.05 \%, 0.10 \%, 0.15 \%$ and $0.20 \%$ BWOC samples cured for 7 and 28 days as 786 a function of the percentage of nanocellulose: Diamonds symbols represent samples cured 787 for 7 days and squares symbols represent samples with 28 days of curing. The values have 788 been normalized to the strength value obtained after 7 days of curing in PC cement.

789 Figure 13. Unconfined Compressive Strength for of Portland Cement (PC) and PC modified 790 with BNC at $0.05 \%, 0.10 \%, 0.15 \%$ and $0.20 \%$ BWOC samples at three curing times: $8 \mathrm{~h}, 7$ 791 days and 28 days.

792 Table 1. Cement chemical composition.

\begin{tabular}{cccccccc}
\hline Composition & $\mathrm{CaO}$ & $\mathrm{SiO}_{2}$ & $\mathrm{MgO}$ & $\mathrm{Al}_{2} \mathrm{O}_{3}$ & $\mathrm{Fe}_{2} \mathrm{O}_{3}$ & $\mathrm{SO}_{3}$ & $\begin{array}{c}\text { Total } \\
\text { alkalieq }\end{array}$ \\
\hline (wt\%) & 62.39 & 21.23 & 2.22 & 3.84 & 5.07 & 2.40 & 0.64 \\
\hline
\end{tabular}

Table 2. Bacterial nanocellulose content in cement paste.

\begin{tabular}{cccccccc}
\hline Mix & $\begin{array}{c}\text { Additive } \\
{[\mathrm{g}]}\end{array}$ & $\begin{array}{c}\text { BNC } \\
{[\mathrm{g}]}\end{array}$ & Added Water[g] & $\begin{array}{c}\text { Water } \\
{[\mathrm{g}]}\end{array}$ & $\begin{array}{c}\text { Total water } \\
{[\mathrm{g}]}\end{array}$ & $\begin{array}{c}\text { Cement } \\
{[\mathrm{g}]}\end{array}$ & $\begin{array}{c}\text { BNC content } \\
{[\%]}\end{array}$ \\
\hline 1 & 0 & 0 & 0 & 349 & 349 & 792 & 0.00 \\
2 & 86.09 & 0.40 & 85.69 & 263.31 & 349 & 792 & 0.05 \\
3 & 172.17 & 0.79 & 171.38 & 177.62 & 349 & 792 & 0.10 \\
4 & 258.26 & 1.19 & 257.07 & 91.93 & 349 & 792 & 0.15 \\
5 & 342.80 & 1.58 & 341.22 & 7.78 & 349 & 792 & 0.20 \\
\hline
\end{tabular}

796 Table 3. Consistometry test.

\begin{tabular}{ccccc}
\hline Test & $\begin{array}{c}\text { BNC } \\
{[\%]}\end{array}$ & $\begin{array}{c}\text { SP } \\
{[\%]}\end{array}$ & $\begin{array}{c}\text { Initial consistency } \\
{[\text { Bearden] }}\end{array}$ & Thickening time [min] \\
\hline 1 & 0 & 0 & 15 & 99 \\
2 & & 0.05 & Excessively viscous & - \\
3 & & 0.15 & Excessively viscous & - \\
4 & 0.05 & 0.3 & Excessively viscous & - \\
5 & & 0.35 & 35 & 99 \\
6 & & 0.4 & 12 & 126 \\
\hline
\end{tabular}

798 Table 4. $\mathrm{CH}$ content and $\mathrm{DOH}(\%)$ of the samples.

\begin{tabular}{cccc}
\hline Sample & BNC [\%] & $\mathrm{CH}[\%]$ & $\mathrm{DOH}[\%]$ \\
\hline 1 & 0 & $19.92 \%$ & 62.96 \\
2 & 0.05 & $22.16 \%$ & 66.13 \\
3 & 0.1 & $22.45 \%$ & 64.62 \\
4 & 0.15 & $22.67 \%$ & 68.34 \\
5 & 0.2 & $22.58 \%$ & 66.88 \\
\hline
\end{tabular}

800 Table 5. BNC and SP percentages in cement samples.

\begin{tabular}{ccccccc}
\hline \multicolumn{2}{c}{ Sample } & $\begin{array}{c}\text { Cement } \\
{[\mathrm{g}]}\end{array}$ & $\begin{array}{c}\text { Water } \\
\text { [g] }\end{array}$ & $\begin{array}{c}\text { Curing } \\
\text { [days] }\end{array}$ & $\begin{array}{c}\text { BNC } \\
\text { [\% BWOC] }\end{array}$ & $\begin{array}{c}\text { SP } \\
\text { [\% BWOC] }\end{array}$ \\
\hline 1 & - & 792 & 349 & 7 & 0 & 0 \\
2 & - & 792 & 349 & 7 & 0.05 & 0.4 \\
3 & - & 792 & 349 & 7 & 0.10 & 0.4 \\
\hline
\end{tabular}




\begin{tabular}{ccccccc}
\hline 4 & - & 792 & 349 & 7 & 0.15 & 0.55 \\
5 & - & 792 & 349 & 7 & 0.20 & 0.7 \\
- & 1 & 792 & 349 & 28 & 0 & 0 \\
- & 2 & 792 & 349 & 28 & 0.05 & 0.35 \\
- & 3 & 792 & 349 & 28 & 0.10 & 0.35 \\
- & 4 & 792 & 349 & 28 & 0.15 & 0.5 \\
- & 5 & 792 & 349 & 28 & 0.20 & 0.6 \\
\hline
\end{tabular}

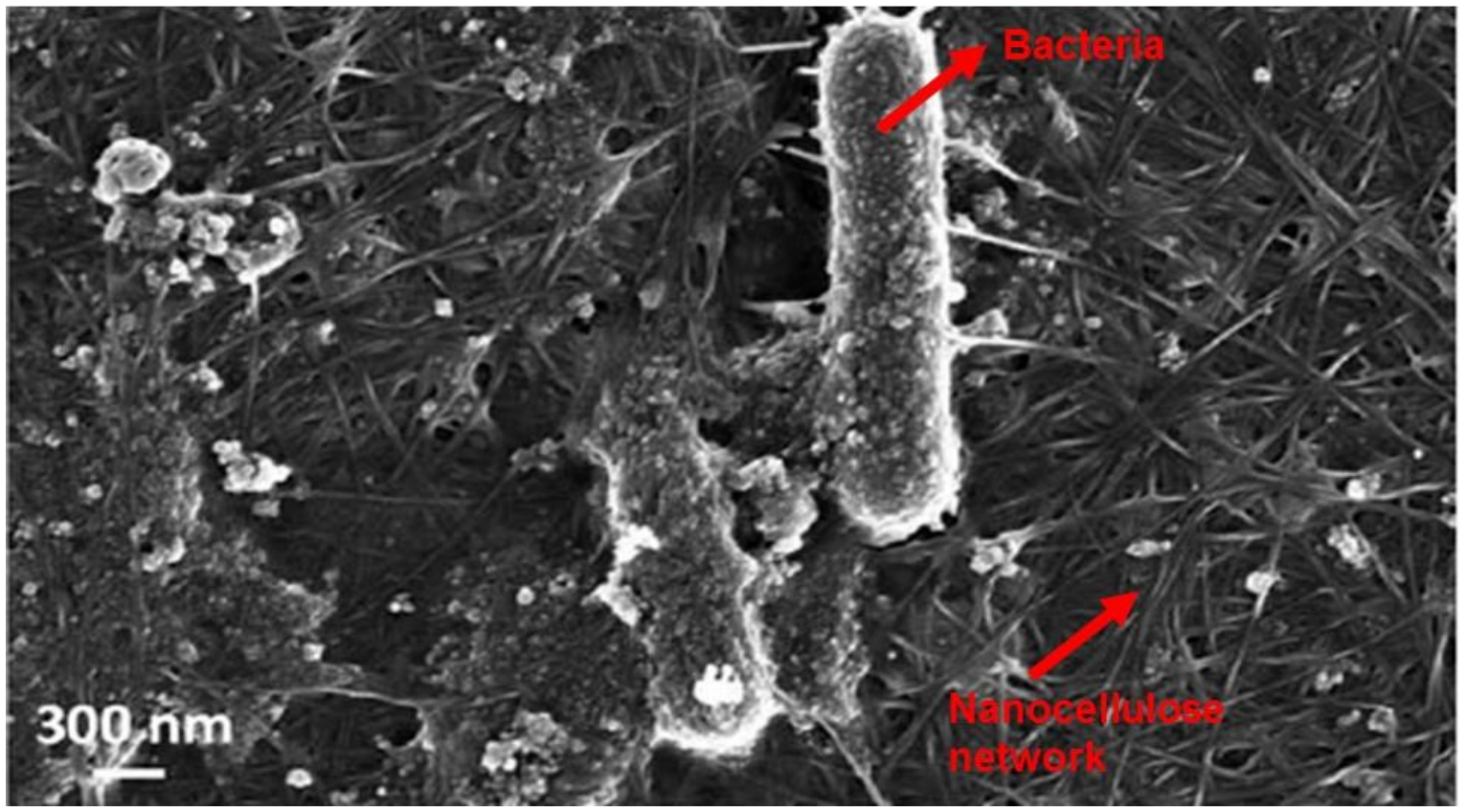

804 Figure 1. Bacteria and bacterial nanocellulose (Courtesy of Cerruti et al. 2016) 805 


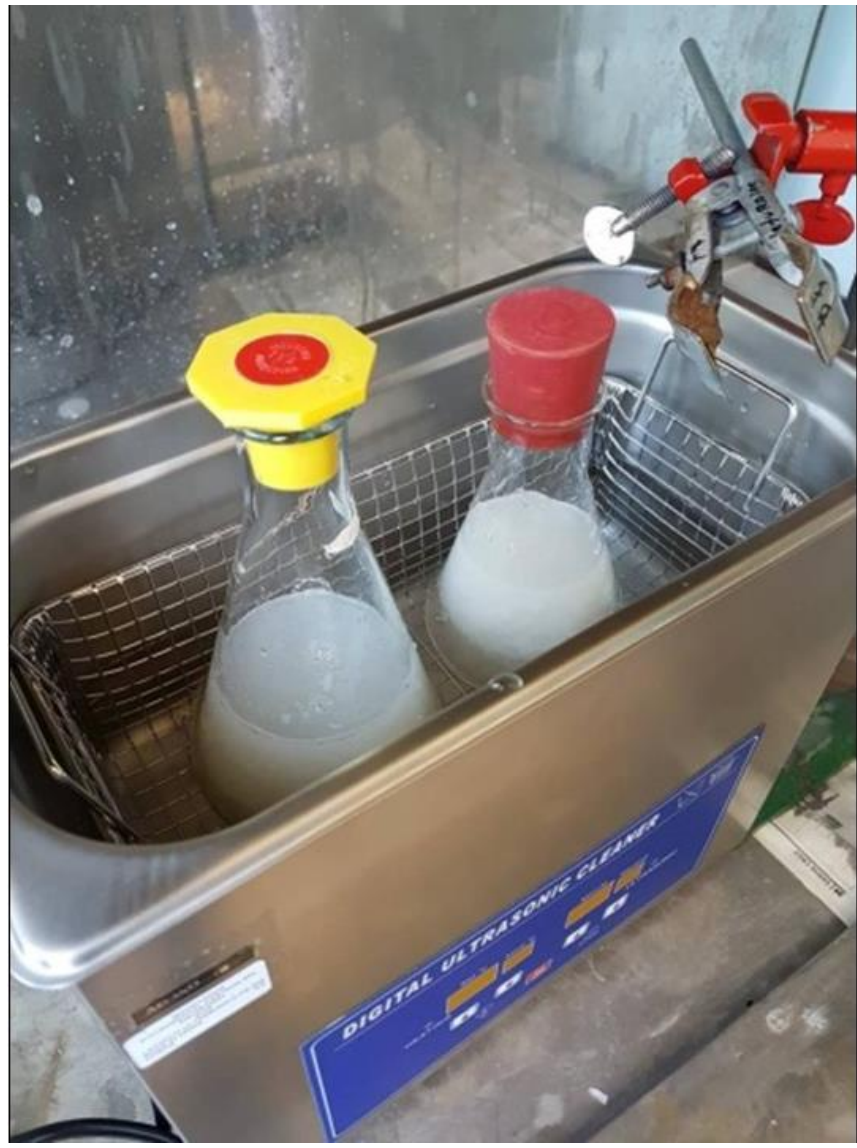

807 Figure 2. Ultrasonic bath for homogenization of BNC - distilled water mixture.
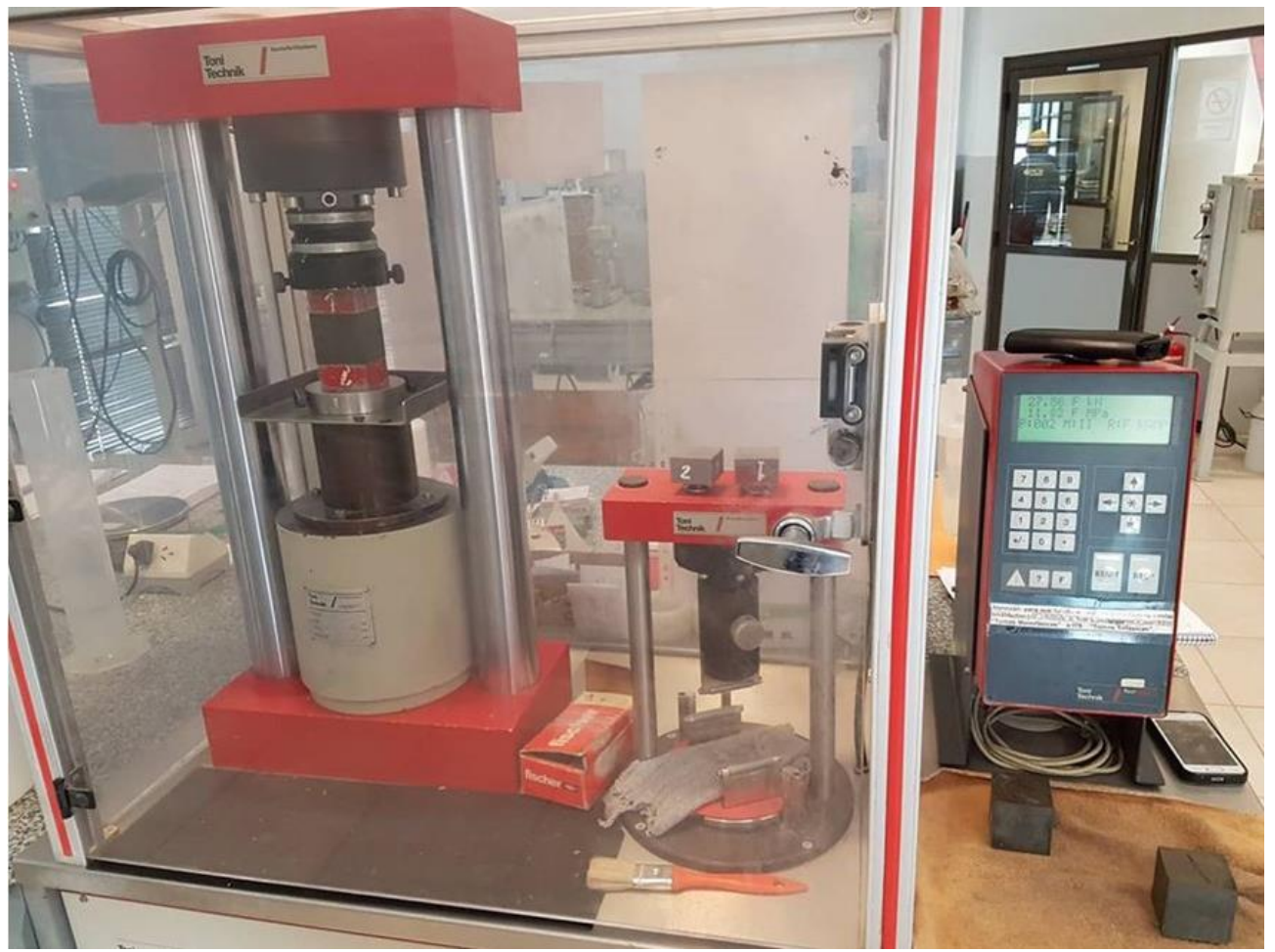

Figure 3. Compressive strength test equipment. 
811

812 813
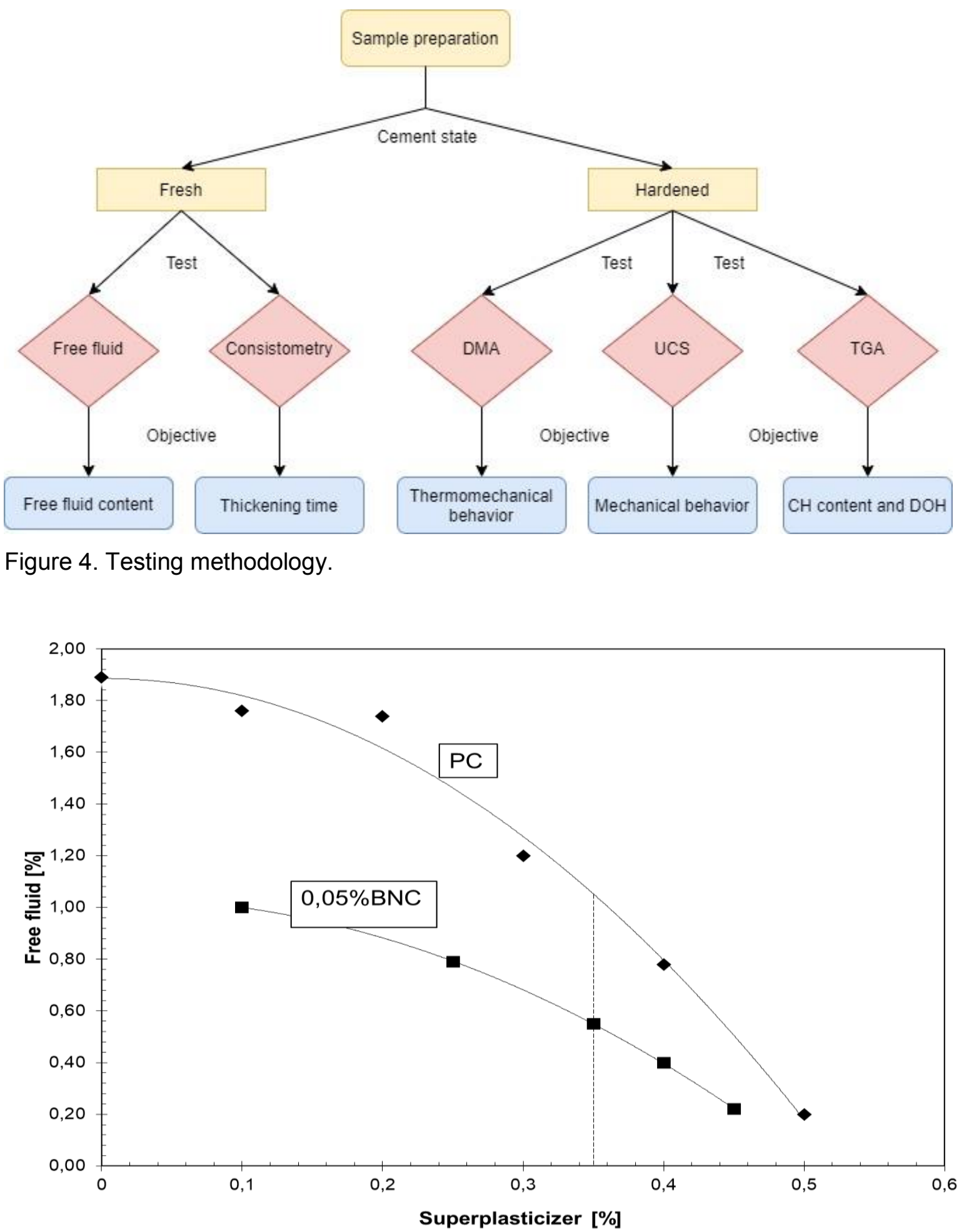

814

815 Figure 5. Free fluid content for different percentages of superplasticizer for Portland 816 Cement (PC) and PC + 0.05\% BNC. 


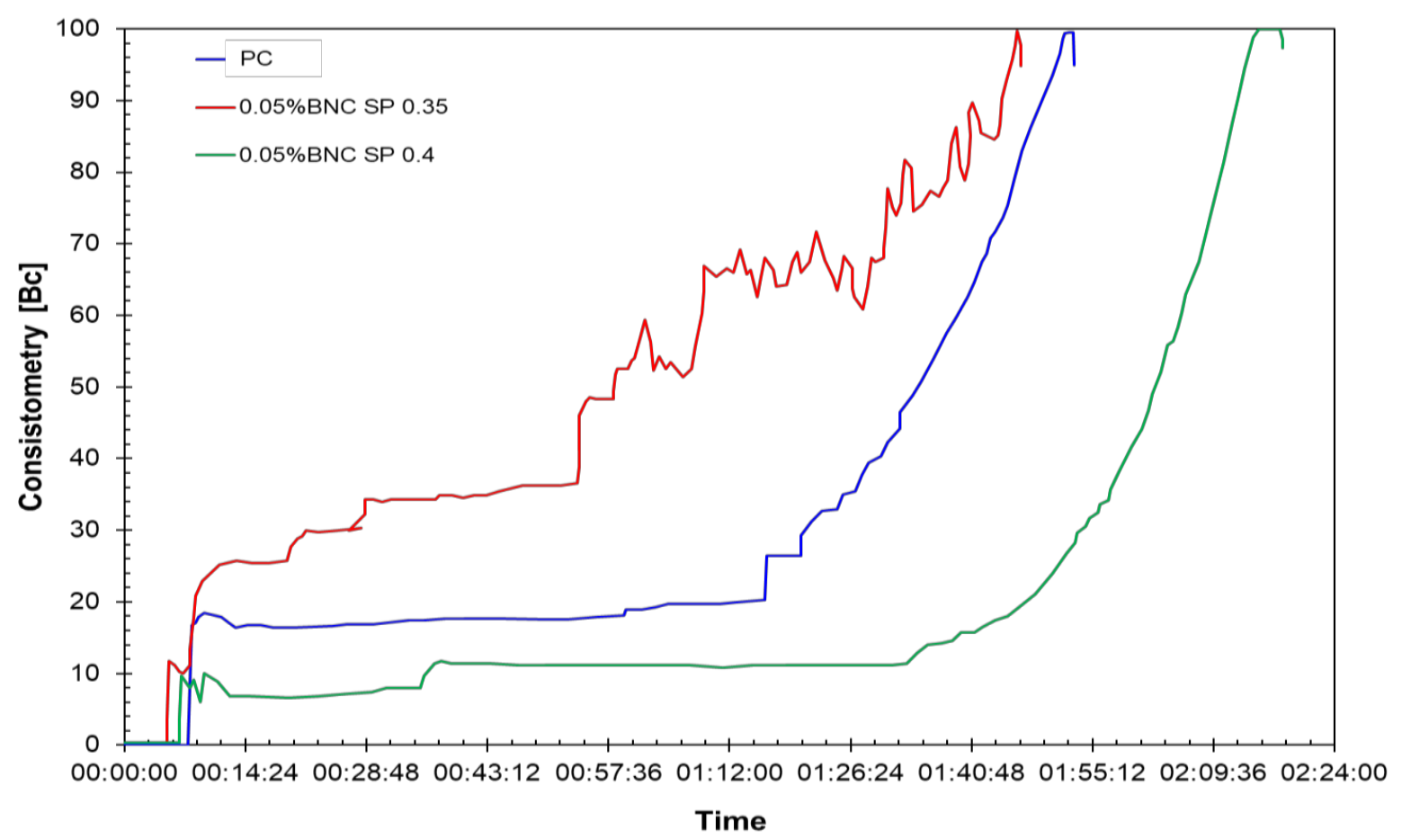

819 Figure 6. Consistometry test for Portland Cement (PC), PC $+0.05 \%$ of BNC $+0.35 \%$ SP 820 and $\mathrm{PC}+0.05 \% \mathrm{BNC}+0.40 \% \mathrm{SP}$.

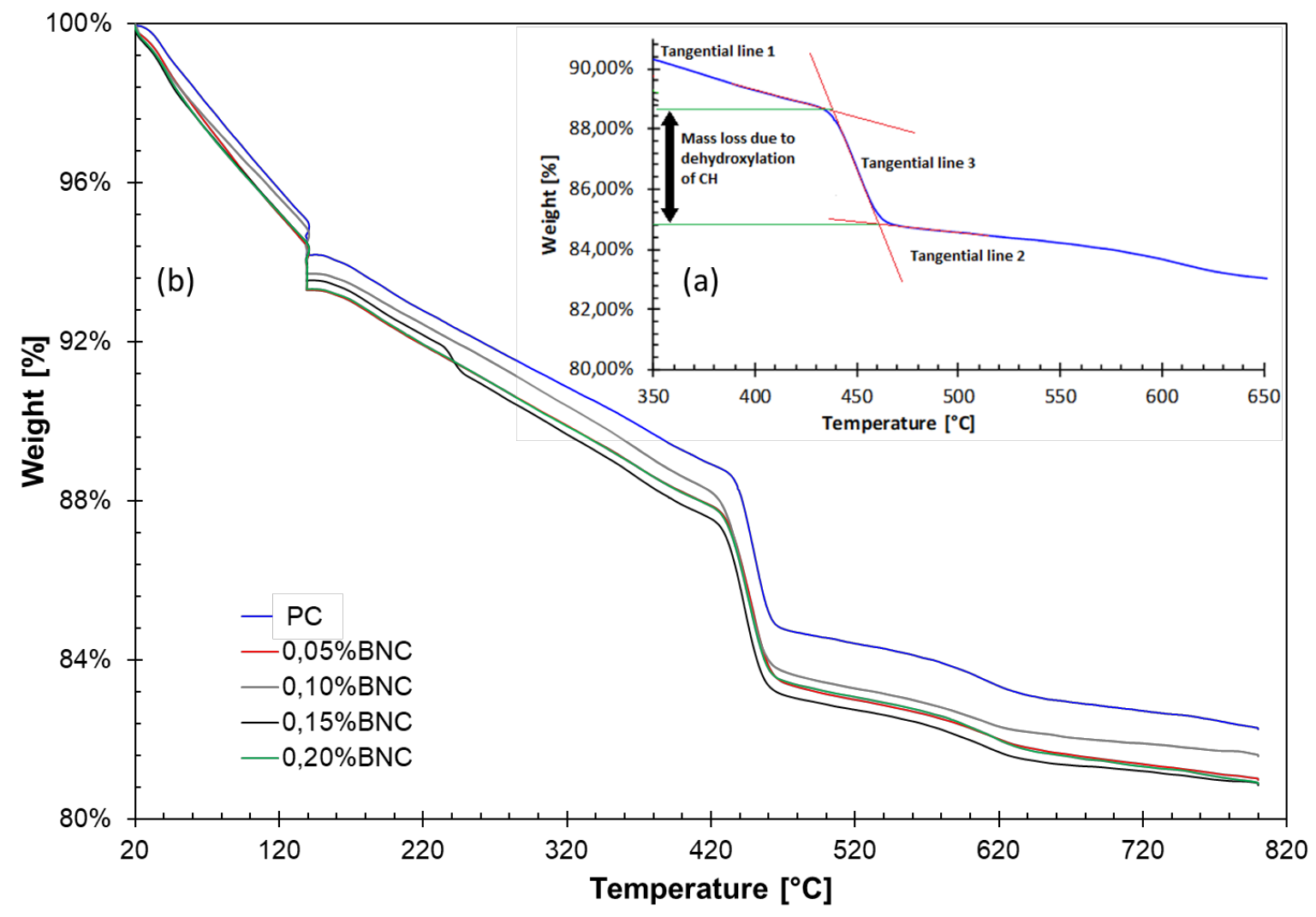

822 Figure 7. (a) Example of mass loss calculation for $\mathrm{CH}$ in the TGA test (b)TGA results for 823 Portland Cement (PC) and PC modified with BNC at $0.05 \%, 0.10 \%, 0.15 \%$ and $0.20 \%$ 824 BWOC. 


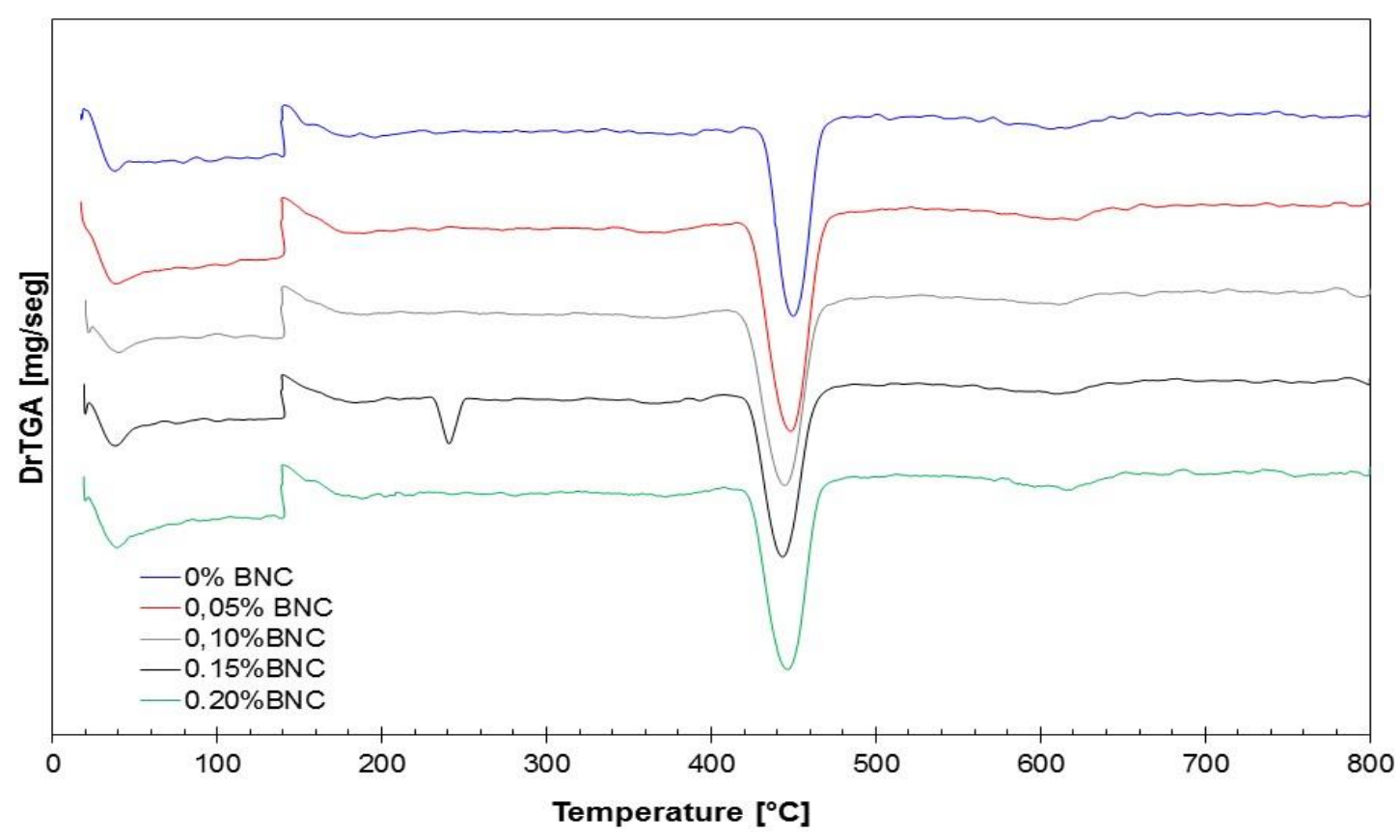

826 Figure 8. DrTGA results for Portland Cement (PC) and PC modified with BNC at $0.05 \%$, $0.10 \%, 0.15 \%$ and $0.20 \%$ BWOC.

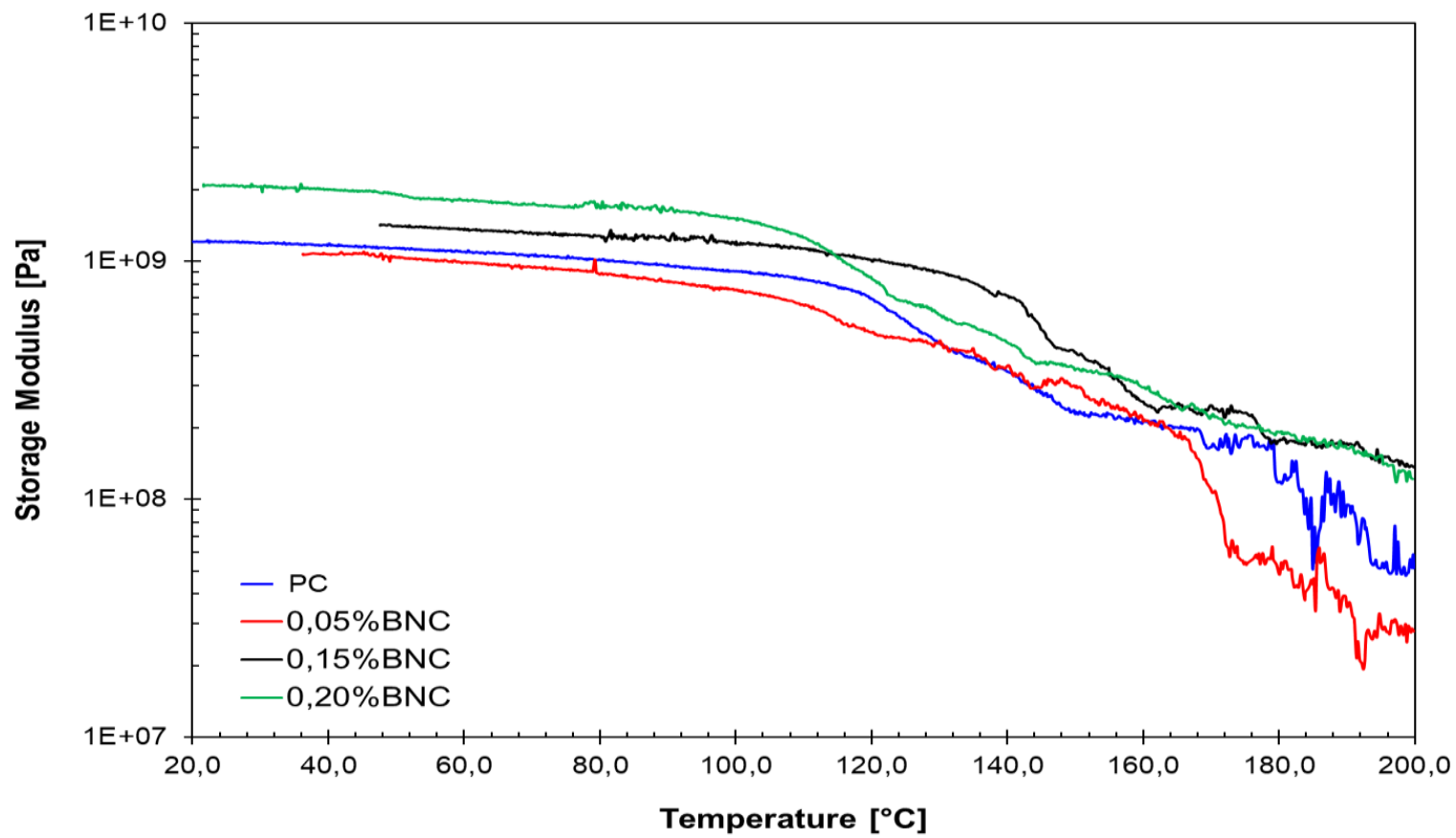

829 Figure 9. DMA results of Portland Cement (PC) and PC modified with BNC at $0.05 \%$, $830 \quad 0.10 \%, 0.15 \%$ and $0.20 \%$ BWOC samples cured for 28 days. 


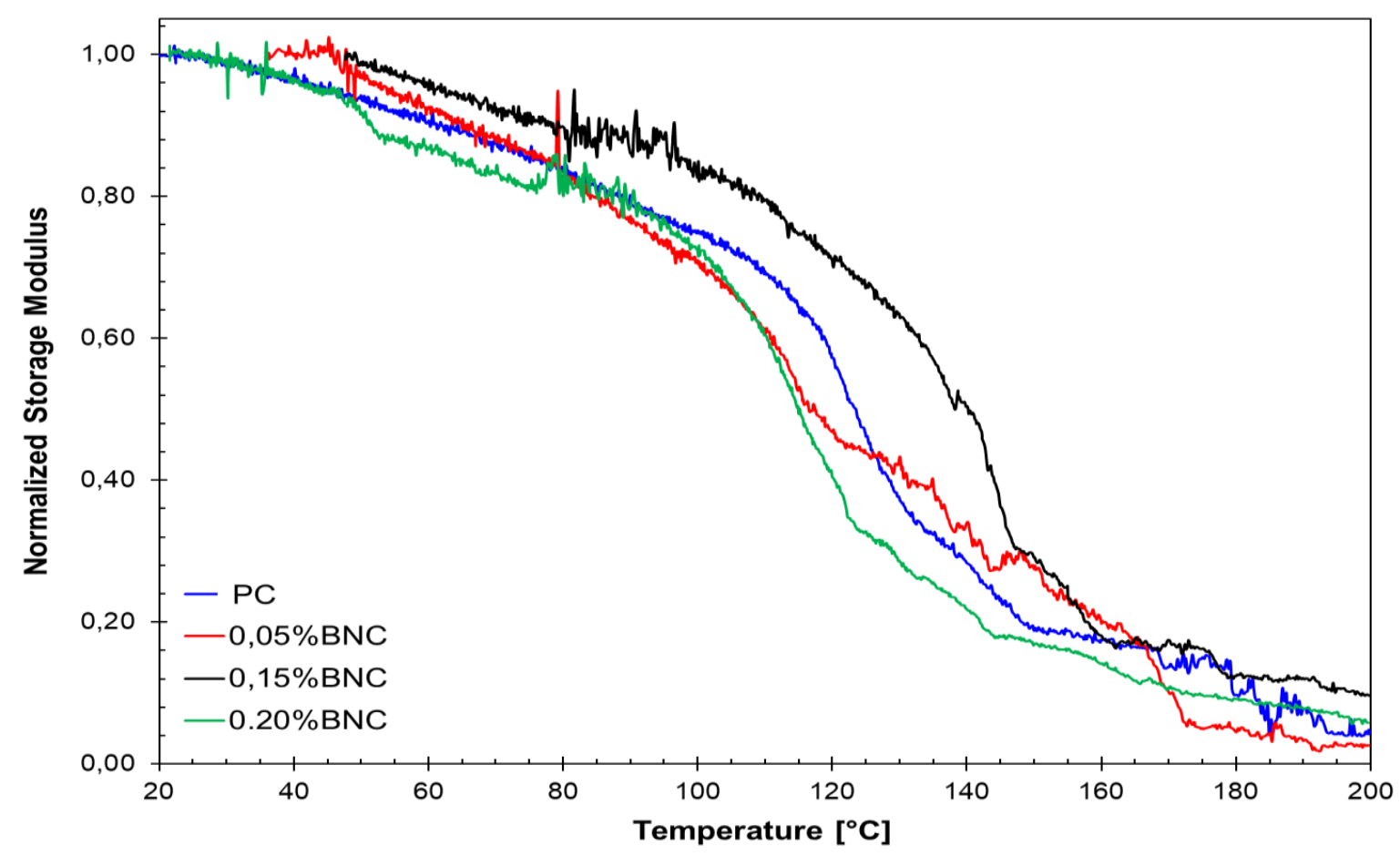

831

832 Figure 10. Normalized storage modulus of Portland Cement (PC) and PC modified with 833 BNC at $0.05 \%, 0.10 \%, 0.15 \%$ and $0.20 \%$ BWOC samples cured for 28 days.

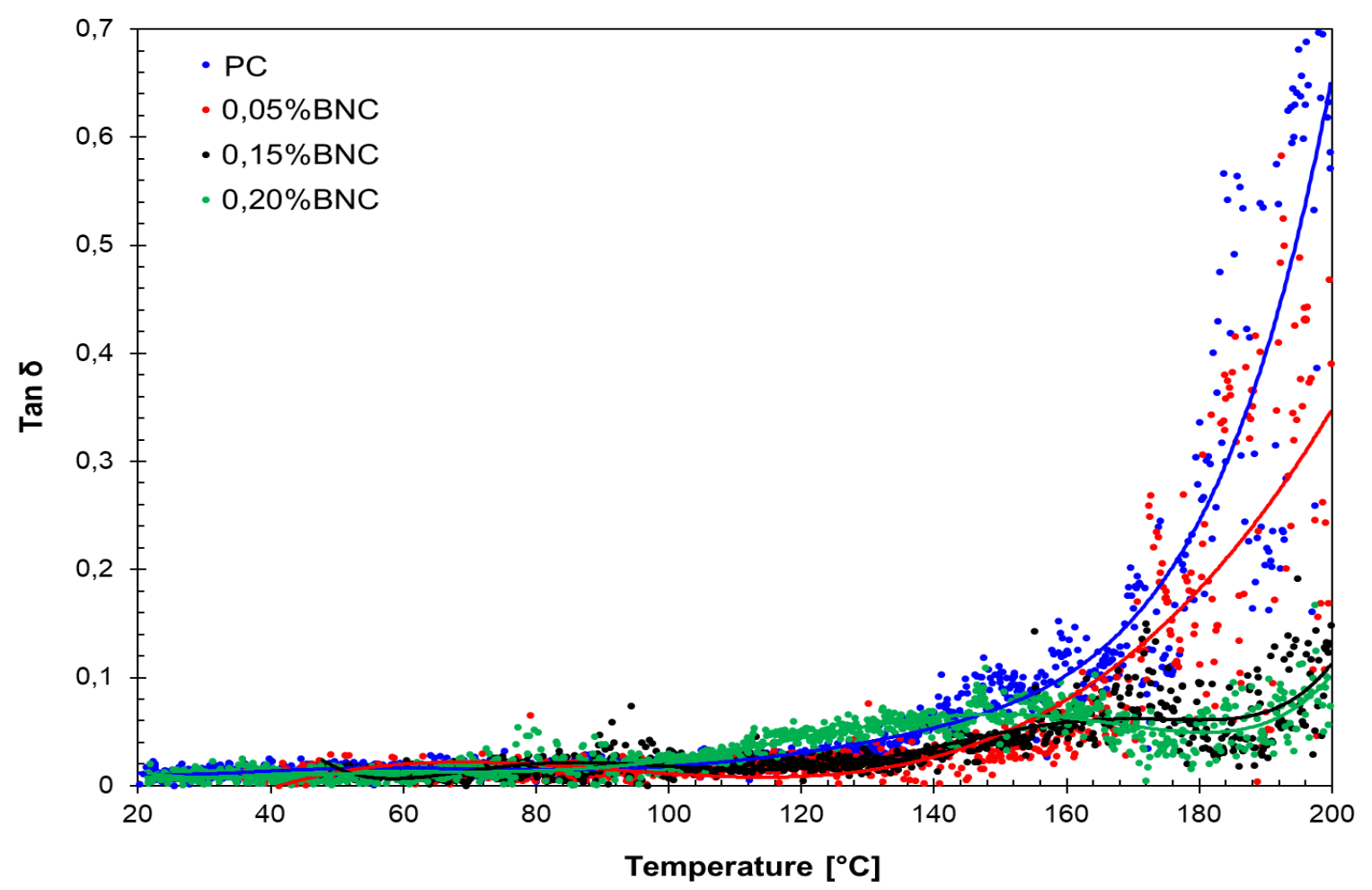

836 Figure 11. DMA results in term of $\tan \delta$ of Portland Cement $(P C)$ and PC modified with BNC 837 at $0.05 \%, 0.10 \%, 0.15 \%$ and $0.20 \%$ BWOC samples cured for 28 days. 


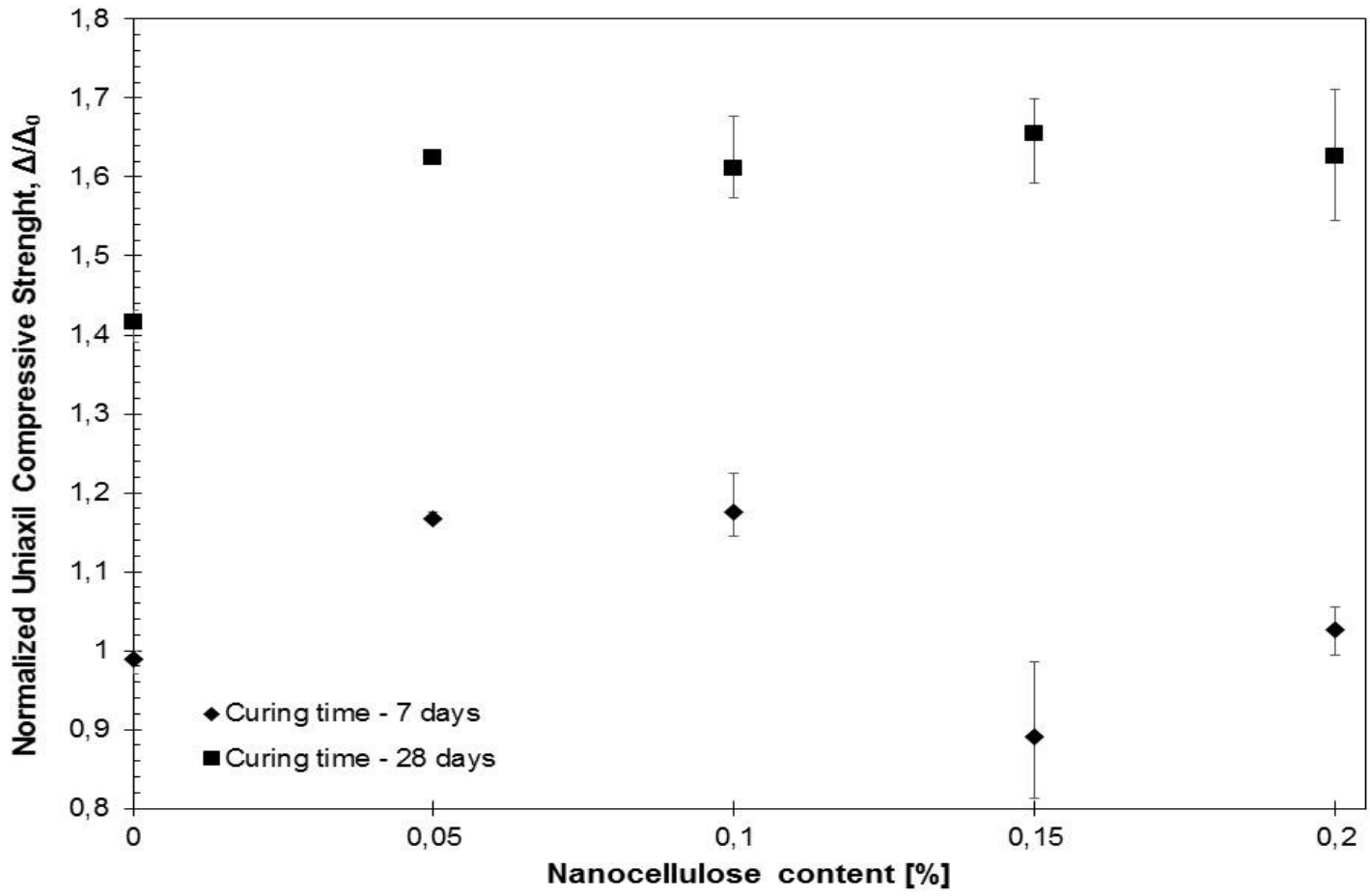

839 Figure 12. Normalized compressive strength of Portland Cement (PC) and PC modified 840 with BNC at $0.05 \%, 0.10 \%, 0.15 \%$ and $0.20 \%$ BWOC samples cured for 7 and 28 days as 841 a function of the percentage of nanocellulose: Diamonds symbols represent samples cured 842 for 7 days and squares symbols represent samples with 28 days of curing. The values have 843 been normalized to the strength value obtained after 7 days of curing in PC cement. 


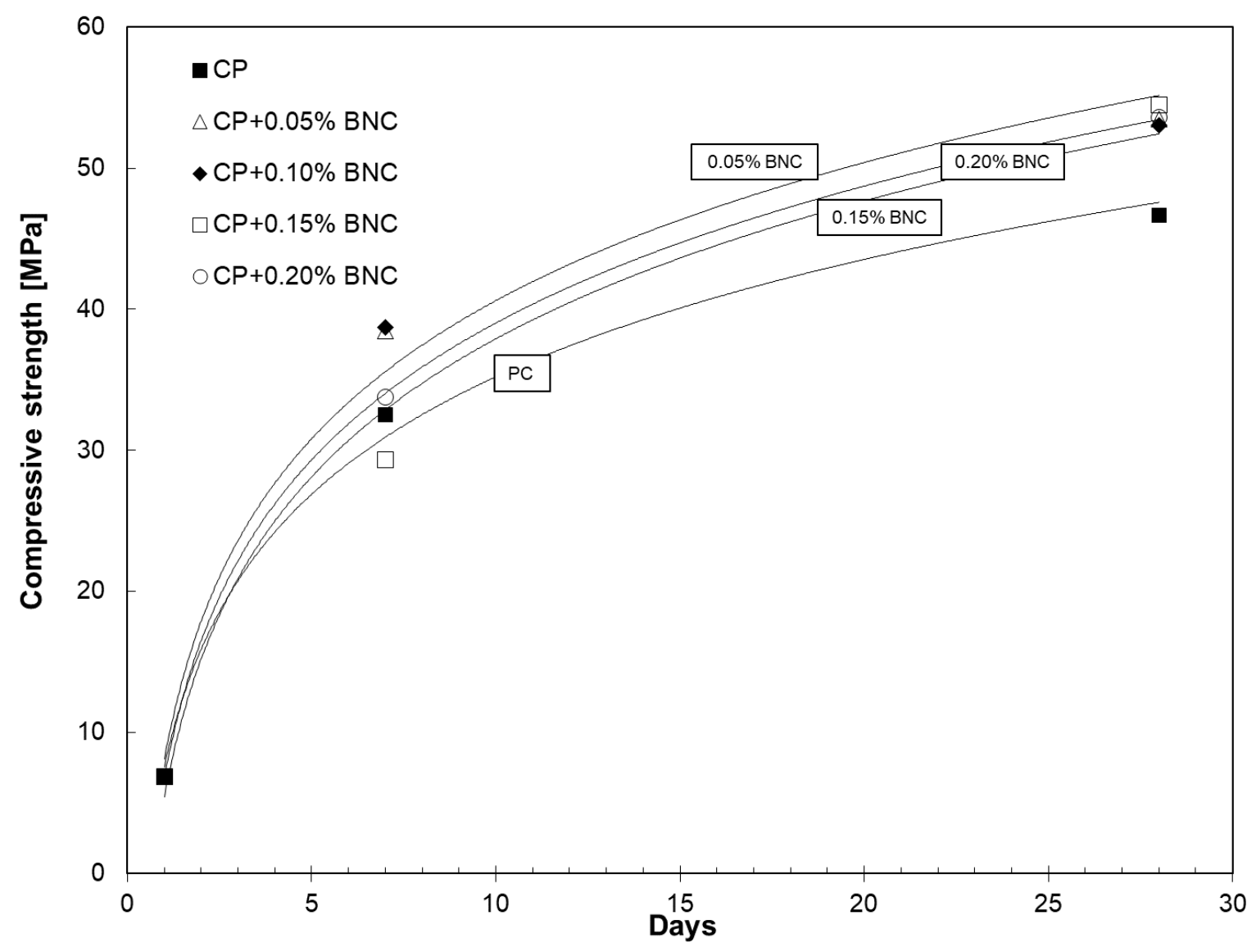

845 Figure 13. Unconfined Compressive Strength for of Portland Cement (PC) and PC modified 846 with BNC at $0.05 \%, 0.10 \%, 0.15 \%$ and $0.20 \%$ BWOC samples at three curing times: $8 \mathrm{~h}, 7$ 847 days, and 28 days. Only the average values of the results were considered. 


\section{Highlights}

Incorporation of bacteria nano cellulose in oil-well cement improves the strength of hardened samples.

Thermogravimetric analysis shows an increment in hydration products and hydration degree with bacterial nanocellulose

Enhancement of thermal stability and tensile reinforcement has been observed using large percentages of bacterial nanocellulose. 